\title{
The Paracelsian Impetus
}

Paracelsianism was named after presumably the most enigmatic physician of the sixteenth century, Paracelsus (real name, Philippus Aureolus Theophrastus

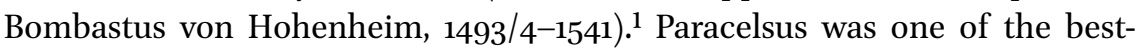
known physicians of the century preceding the publication of the manifestos, a key figure in the transformation of medicine, and an outlandish figure announcing imminent changes in the world. He is also the sole recent historical figure mentioned in the manifestos. ${ }^{2}$ In order to appreciate the full meaning of the general reformation and Paracelsus' influence on the manifestos, it is necessary to introduce this physician as well as the movement he engendered in some detail.

Paracelsus was the son of physician Wilhelm von Hohenheim, who introduced Paracelsus to medicine from an early age onwards. His mother is presumed to have worked in the famous Benedictine monastery of Einsiedeln, and died when Paracelsus was still a young boy. ${ }^{3}$ In 1516, Paracelsus recalled, he received the degree of doctor in Ferrara, Italy. ${ }^{4}$ In his early years as a physician, he became increasingly famous as a practitioner of the new healing arts and for the use of alchemically prepared cures, but his antithetical attitude toward

1 Although the name "Paracelsus" came about only after his Basel period (ca. 1527), Theophrastus Paracelsus will be referred to by that name throughout this study. A few well-known studies on Paracelsus' life include: Goldammer, Paracelsus. Natur und Offenbarung; Pagel, Paracelsus. An Introduction; Webster, Paracelsus. Medicine, Magic; Weeks, Paracelsus. Speculative Theory and the Crisis of the Early Reformation; idem, Paracelsus. Essential Theoretical Writings.

2 Cf. below, section 2.4.

3 See also Paracelsus, Liber de re templi ecclesiastica, NPE 1, 364, where Paracelsus lists Einsiedeln among other places of pilgrimage. For a brief summary of Paracelsus' career, see: Webster, Paracelsus, 9-33.

4 Paracelsus testifies to this in a Basel document dated 21 May 1527, and in several works he referred to himself as a "doctor" of medicine. The document is transcribed in: Blaser, Paracelsus in Basel, 68-69; see also: Benzenhöfer, "Paracelsus," 7-8; Kamenzin, "Paracelsus und die Universitäten," 148-152. No documents indicating Paracelsus' enrolment at Ferrara have survived. On his studies with his father, see: Paracelsus, Die grosse Wundarznei, I, 10; 354. Because the Sudhoff and Goldammer editions also include religious writings (part 2), these editions will be referred to for Paracelsus' and pseudo-Paracelsus' works, sometimes complemented by the Huser edition and the Neue Paracelsus-Edition edited by Gantenbein. 
established medicine had a dramatic impact on his life. The turning point came while he was working as professor in Basel. Paracelsus was invited to Basel to become the official city physician and professor of medicine at its university, and in 1527 he settled in that town. ${ }^{5}$ As professor, he never adjusted himself to the institutional customs and conservatism of that university. He lectured in German rather than in the obligatory Latin and used a different, new terminology. He openly and rigorously rejected the traditional medical authorities who were still taught at the university. The culmination of Paracelsus' opposition to the authorities was when, on St. John's Eve, 23June 1527, he threw a copy of the standard medical textbook of the time, most likely Avicenna's Canon of Medicine, into a bonfire. In his recollection of the event, Paracelsus wrote: "I have thrown the summa of books in the fire of Saint John, so that all misery would rise up in the air together with the smoke."6 It comes as no surprise that his antagonistic attitude and this event in particular met with much hostility in Basel. Soon, his views were ridiculed in verses wherein he was styled Cacophrastus (shit-speaker), as opposed to Theophrastus (god-speaker). ${ }^{7}$ According to his own testimony, he was mocked, laughed at, and was even pelted with urine. ${ }^{8}$ After this event, Theophrastus changed his name to Paracelsus, was forced to leave Basel by decree of the city council, and his medical career took a turn for the worse. ${ }^{9}$ He travelled from town to town but was unsuccessful in finding a more permanent place of residence or a publisher to print his prolific body of works. ${ }^{10}$ Learned communities preferred not to associate themselves with such an outlandish figure.

5 On Paracelsus in Basel, see: Blaser, Paracelsus in Basel. On the invitation, see: Daniel, "Paracelsus' Astronomia Magna," 29-30.

6 Paracelsus, Paragranum, I, 8; 58: "ich hab die summa der bücher in sanct Johannes feuer geworfen, auf das alles unglück mit dem rauch in luft gang [...]." For an account of the bonfire in Basel, see: Ibid., I, 8; 43, 58. Paracelsus did not specify the book he burned, but the reformer Sebastian Franck recalled this event and explained that Paracelsus had burned Avicenna's book. He described Paracelsus as a rare and strange man, who stood alone against all physicians: Franck, Chronica, Zeitbuch und Geschichtsbibel (1531), fol. $253^{\mathrm{r}}$.

7 Paracelsus was mocked in verses entitled The Ghost of Galen against Theophrastus, or rather Cacophrastus (Manes Galeni adversus Theophrastum sed potius Cacophrastum). On these verses, see: Blaser, Paracelsus in Basel, 82-102; Webster, Paracelsus, 13, 39-43.

8 Paracelsus, Paragranum, I, 8; 43 .

9 "Paracelsus" may refer to 'beside' or 'past' (para) Celsus, the Roman physician Cornelius Celsus, but Webster points out that this was never claimed by Paracelsus himself, see:Webster, Paracelsus, 40-41.

Kamenzin, "Paracelsus und die Universitäten," 157-158. 


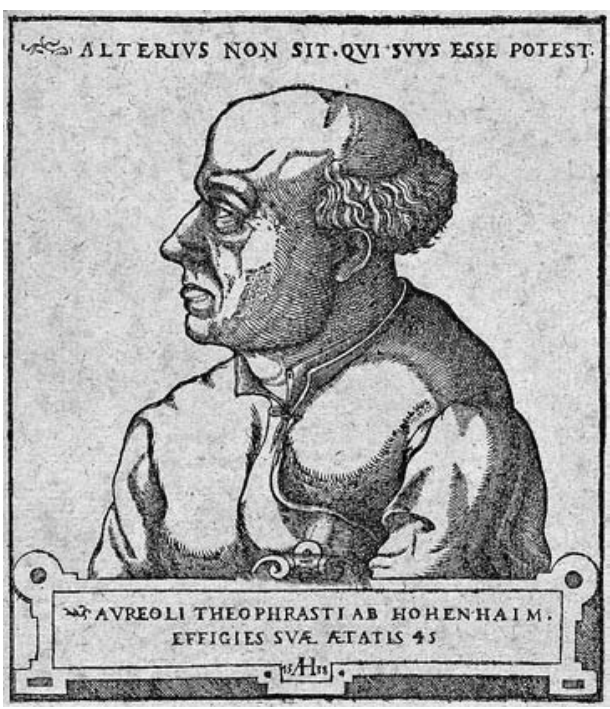

FIGURE 4 Paracelsus, woodcut by A. Hirschvogel, Wellcome Collection

During his life, Paracelsus had become notorious as a chemical physician, but twenty years after his death his works became increasingly popular. Important physicians contributed immensely to Paracelsus' renown at the end of the sixteenth and beginning of the seventeenth centuries. They published editions of Paracelsus' works or wrote works themselves that contributed to his popularity, and soon his works issued from various printing presses. ${ }^{11}$ Owing to this proliferation of publications, his ideas spread over Europe. Enthusiasts began writings tracts in his name to attract a readership, and translations of his works and new books inspired by his ideas were published not only in Germany and Switzerland, the regions where Paracelsus had spent most of his life, but also in England, France, Denmark, the Netherlands, and Sweden. ${ }^{12}$ With such an outpouring of Paracelsian writings, it was inevitable that the enigmatic figure and his early reception would have come to the attention of the authors of the manifestos.

11 See: Sudhoff, Einleitendes, I, 1; vii-xlviii; idem, Vorwort, I, 2; v-xxxi. See, for example: Thurneysser, Onomasticon (1574-1583); Dorn, Dictionarium Theophrasti Paracelsi continens obscuriorum vocabularum, quibus in suis scriptis passim utitur definitiones (1584); Paracelsus (ed. Huser), Der Bücher und Schrifften/des Edlen/Hochgelehrten und Bewehrten Philosophi unnd Medici, Philippi Theophrasti Bombast von Hohenheim/ Paracelsi genannt, 10 vols. Cf. Kühlmann and Telle, Corpus Paracelsisticum, vols. 1-3. Kahn, "Alchimie et Paracelsisme," 94-98; Daniel, "Paracelsus' Astronomia Magna," 93-99.

12 Cf. Debus, The English Paracelsians; idem, The French Paracelsians; Kühlmann and Telle, Corpus Paracelsisticum, vols. 1-3. 
Paracelsus' influence on the manifestos is not a new topic. In the available historiography on the manifestos, Paracelsus' role and Paracelsian themes have been widely acknowledged, with a special focus on the Paracelsian elements within the manifestos, such as the microcosm-macrocosm analogy, Paracelsus' theory of signatures, and the specific invocation of the "Book of Nature."13 Yet, a thorough analysis has remained a desideratum, while also Paracelsus' religious and apocalyptic considerations have not yet been considered in relation to the Rosicrucian texts. ${ }^{14}$ Equally neglected in this context are the strong pseudoParacelsian and early-Paracelsian currents of thinking. There is still a need to trace the manifestos and specifically their call for a general reformation and related themes back to pseudo-Paracelsian and sixteenth-century Paracelsian texts. ${ }^{15}$ To what extent did Paracelsus and his early followers excite and inspire this central aim in the manifestos? The eschatological and millenarian expectations, apocalyptic beliefs, and alchemical, medical, and finally philosophical considerations surfacing in this profusion of Paracelsian literature in the years preceding the composition of the manifestos require careful examination in order to establish a Paracelsian impetus for the Rosicrucian notion of a general reformation.

13 Examples include: Kienast, Johann Valentin Andreae und die Vier echten RosenkreutzerSchriften, 120; Trevor-Roper, Renaissance Essays, 182; Edighoffer, Rose-Croix et société idéale, vol. 1, 270-278; idem, Les Rose-Croix et la crise, 163-178; idem, "L'énigme Paracelsienne”; idem, "Die Manifeste der Rosenkreuzer"; Gilly: Cimelia Rhodostaurotica, 7 ; idem, "Vom ägyptischen Hermes," 71-73; Åkerman, Rose Cross over the Baltic, 12-13; Faivre, Theosophy, Imagination, Tradition, 174-176. On these Paracelsian themes, see below, section 2.4. A comparative study on Paracelsianism(s) still remains pending, and is not the object of this book. Here, the term "Paracelsian" will be used for those who self-identified as followers of Paracelsus.

14 In his "Chiliasmus und soziale Utopie im Paracelsismus," Wollgast briefly discusses chiliasm in Paracelsus' works and subsequently in what he named "Rosicrucianism," but he neglects to discuss the Rosicrucian manifestos, let alone the influence of Paracelsus' chiliastic views on these manifestos. Edighoffer, in turn, discusses Paracelsus' influence on the manifestos in several of his works, but he neither discusses the influence of the following Paracelsian movement on the manifestos nor even mentions Paracelsus' apocalypticism. He does acknowledge a Joachimite influence on the Confessio, but dissociates this from Paracelsianism; see: Edighoffer, Rose-Croix et société idéale, vol. 1, 278-285.

15 Here, in particular the early Paracelsians who were also involved in publishing Paracelsian books, and who were as such responsible for the early dissemination of Paracelsus' ideas, will be taken into account. 
The reform described by the Rosicrucians was expected to take place on the eve of an imminent new age, according to an interpretation of history that was not only teleological, but also cyclical. The Rosicrucian authors expressly drew on Paracelsus throughout their manifestos in support of their predictions. Apocalyptic expectations were not only a central aspect of the Rosicrucian manifestos, but were also a conspicuous feature in the Paracelsian literature, which thereby proved to be a wealthy source of potential influence. ${ }^{16}$ While he was primarily known as a physician, Paracelsus had written extensively on religious matters, which is an aspect of his work that scholars have only recently begun to study in any great depth. ${ }^{17}$ In fact, his most extensive works concern biblical and theological topics, such as his Commentary on the Psalms and his interpretation of Matthew. ${ }^{18}$ Paracelsus started writing in the early phase of the Lutheran Reformation, around 1525, when Luther's views had just begun to spread widely. ${ }^{19}$ Paracelsus' earliest religious writings, such as his On Justice and On Seven Points of Christian Idolatry, concerned much-debated issues of the time..$^{20}$ As was the case with his philosophy and medicine, in his religious

16 For Paracelsus on religious matters, see: Goldammer, "Neues zur Lebensgeschichte und Persönlichkeit des Theophrastus Paracelsus"; "Paracelsische Eschatologie"; idem, "Das Religiöse Denken des Paracelsus"; Guinsburg, "Paracelsian Magic and Theology. A Case Study of the Matthew Commentaries," 125-138; Biegger, 'De invocatione Beatae Mariae virginis'; Kämmerer, “Das Leib-Seele-Geist-Problem”; Gause, Paracelsus; Rudolph, "Paracelsus Laientheologie"; idem, "Hohenheim's Anthropology in the Light of his Writings on the Eucharist"; Haas, "Paracelsus der Theologe"; Weeks, Paracelsus, 36-43; Daniel, "Paracelsus' Astronomia Magna”; Gantenbein, Paracelsus. For Paracelsus' followers on religious matters, see in particular: Murase, "Paracelsismus und Chiliasmus."

17 Goldammer and Matthiessen published in the mid-twentieth century several religious works by Paracelsus, and Goldammer has analysed and discussed several of them: see: Paracelsus, Sämtliche Werke, vols. 1-7, and supplement. Nevertheless, many of Paracelsus' religious works have never been published, and whilst in the last few decades these texts have received proper attention from some scholars, there is still much left to be untangled. Gantenbein has begun publishing religious texts by Paracelsus in the Neue Paracelsus Edition, most of which have never been published before. The first volume of the planned 12 has been published: Gantenbein, Neue Paracelsus-Edition 1, hereafter: NPE.

18 Paracelsus, "Auslegung des dritten Teils des Psalters Davids," II, 4; idem, "Die Auslegung des Psalters Davids," II, 7. Cf. Guinsburg, "Paracelsian Magic and Theology. A Case Study of the Matthew Commentaries."

19 Hillerbrand, The Protestant Reformation, xxv. On Paracelsus and Luther, see: Paracelsus, Paragranum, I, 8; 43-44, 63; Rudolph, "Einige Gesichtspunkte zum Thema 'Paracelsus und Luther."

$20 \quad$ Paracelsus, De iustitia, II, 2; 151-156; idem, De septem punctis, II, 3; 1-58. 
works he deliberately dissociated himself from all authorities, whatever their denomination, believing that the leaders of the established religious groups were all made of "the same cloth." ${ }^{21}$ He worked as a lay theologian, preaching among the "common folk," sympathising with the peasants' movement, and speaking, as he himself stated, "several times in taverns, drinking places, and inns, against senseless church attendance, lavish ceremonies, praying and fasting that are to no avail, alms giving [...]."22 Although Paracelsus argued against all confessions, he associated with some radical reformers, sent letters to Luther and his companions about his own Matthew commentary, and is documented to have chosen to die a Catholic - all of which contributed to the enigma of the man's religious identity. ${ }^{23}$

Despite the direct references to Paracelsus in the manifestos, his apocalyptic views could not have been further removed from the Rosicrucian expectations. In some of his religious writings, Paracelsus made prophetic statements about the future. ${ }^{24}$ Like the Rosicrucians later, he believed the present time on earth to be one of degradation, but that contemporary misery would soon be replaced by a beatific future. As he explained in his On the Genealogy of Christ: "So everything is nothing but a vale of tears, from where we must leave towards another world, where nothing will be but joy and delight in eternity."25

21 Idem, De secretis secretorum theologiae, II, 3; 203, 206: “[...] die dem bapst beistehen, die halten ihn für ein lebendigen heiligen; die dem Ariano beisteen, dergleichen für ein gerechten, die dem Zwingli beistehen, dergleichen für ein gerechten menschen; die dem Luther beistehn, dergleichen für ein rechten propheten [...]. So richten sie sich selbst über einander und schänden antichristen, widerchristen, ketzer; und seindt vier Par Hosen éins Tuchs." See also: ibid., 227.

22 Idem, De septem punctis, II, 3; 3-4: "Euer täglich widerpellen und scharpfreden wider mich von wegen der warheit, so ich etwan und etlich mal in tabernen, krügen und wirtshäusern geredt hab wider das unnütz kirchengehn, üppige feier, vergebens petten und fasten, almusen geben [...], und alle andere dergleichen priesterliche gebott und aufenthaltung, auch mir dasselbig in ein trunkenheit gezogen, darumb, daß in tabernen geschehen ist, und die tabernen für untüchtige örter zu der warheit zu sein anzeigen, und uf das mich ein winkelprediger genant." On Paracelsus' sympathy with the peasants' movement, see: Webster, "Paracelsus: Medicine as Popular Protest." On Paracelsus speaking in taverns, see also: Weeks, Paracelsus, 95.

23 For the letter to Luther, Melanchthon, and Bugenhagen, see: Rudolph, "Einige Gesichtspunkte zum Thema 'Paracelsus und Luther', 36-39. On Paracelsus and the radical reformers, see: Webster, Paracelsus, 184-209. On Paracelsus' testament, see: Dopsch, “Testament, Tod und Grabmal des Paracelsus." Daniel indeed refers to Paracelsus as a "reform Catholic and radical"; see: Daniel, "Paracelsus' Astronomia Magna," 9onı2, 99.

24 See, for example: Paracelsus, De genealogia Christi, II, 3; idem, Auslegung des Psalters, II, 4; idem, Auslegung des Psalters Davids, II, 7; idem, Auslegung der Papstbilder, I, 12.

25 Paracelsus, De genealogia Christi, II, 3; 132-133: “[...] so ist es alles nichts dann ein 
The world's dire conditions were reflected in the spread of diseases and in the miserable lives of the peasants with whom he was acquainted. According to Paracelsus, humans would soon be liberated from their misery: "Our joy arrives, our golden world, as God Himself will weed out the vineyard and repair the fence, so that there will be no more gaps for a Judas." ${ }^{26}$ The new world will be one of perfection and bliss to be instigated by God, and misery and deception were to be endured only until God's intervention.

In ancient Greek sources, the Golden Age was an age of splendour to be followed by a gradual decline. In Hesiod's Works and Days, an age of peace and splendour had once been in the world, characterised as Gold, which was followed by ages of Silver, Bronze, Heroic, and finally Iron. During the Renaissance, the myth emerged that after the decline of history, the Golden Age was to return again in all of its glory. This myth was promulgated by authors such as Marsilio Ficino (1433-1499). ${ }^{27}$ This view was akin to the one expressed in the Rosicrucian manifestos: the new age was to see misery and imperfection disappear and be replaced by a new citadel of truth, as prelapsarian conditions were restored to the world. ${ }^{28}$

Unlike the Rosicrucians, Paracelsus, who seems to have read Ficino, ${ }^{29}$ did not expect any improvement or perfection before the end of the present world, but awaited a new time only after Christ's Last Judgement. ${ }^{30}$ He shared the widely held belief that the grisly conditions of the present times were to be endured only until Christ will stand in judgement and the righteous will be allowed to enter the New Jerusalem. In his Interpretation of the Images of the Pope (ca. 1532), Paracelsus' edition of the famous medieval Prophecies about the Popes (Vaticinia de summis pontificibus), he aligned himself to the Lutheran expectation of an imminent end from which the manifestos deviated:

jammertal, aus dem wir müessen in ein andere welt, da nichts wird sein als freud und lust in ewigkeit."

26 Idem, Auslegung des Psalters, II, 4; 107: "Do kombt unser freud, unser gulden welt, so uns got im weingarten selbst ausreuten wird und den zaun ganz machen, daß kein Judas lucken mehr do werden sein."

27 Ficino, letter to Paul of Middelburg, Opera omnia, 944. On the Golden Age in the Renaissance, and a chapter on its prehistory, see: Levin, The Myth of the Golden Age in the Renaissance.

28 Confessio, 53-54.

29 Paracelsus, Begleitbrief an Clauser (1527), I, 4; 71.

30 Amadeo Murase has mistakenly attributed an optimistic view of future earthly splendour to Paracelsus, arguing that Paracelsus expected another age before Christ's Second Coming: Murase, "Paracelsismus und Chiliasmus," 11-19. 
Another day will come, after the Last Judgement, in which there will live and be happy those that dwell on earth [...], and the devil in the snake will be in Hell, and not on earth, but bound in the abyss of the deeps of hellfire. And the people on earth will be without heresy, there will be no false apostles, no false prophets, no false Christians. ${ }^{31}$

The golden world is equated, not with a future earthly period before the end of history, but with the time of the New Jerusalem of the Book of Revelation 21-22. But Paracelsus also drew on Revelation 20, which speaks of the binding of Satan (the snake) in the abyss during the millennium. Uniquely, Paracelsus combines these two prophecies as he situates the binding of Satan in the time after the Last Judgement, which means that Satan is bound in hell, not during the millennium, but at the time of the New Jerusalem. There, according to Paracelsus' Interpretation of the Psalms of David, the world will be devoid of all evil and cold, snow will feel "like wool from sheep," soft and warm, while "the poor and miserable should be joyful in Jerusalem, they will play the harp and sing." 32

The delight of the New Jerusalem would entail the inversion of the social order, an inversion of everyday life on earth: the poor will thrive but the rich will be miserable. ${ }^{33}$ Within the manifestos, there is no such commendation of poverty for the sake of a new world in the New Jerusalem. Their authors instead characterised their society as one rich in gold and gems for the benefit of the present world. But Paracelsus' views were akin to those of the peasant reformers in Salzburg. During the Peasants' War of ${ }^{1525}$, he worked as a physician in Salzburg and had associates amongst the reformers. ${ }^{34}$ In his religious writings of the time, he expressed his concern for the welfare of the peasants.

31 Paracelsus, Auslegung der Papstbilder, I, 12; 555: “[...] es wird dornach nach disem jüngsten tag ein ander tag komen, dorin werden leben und frölich sein, die auf Erden wonen [...] und der teufel in der schlangen wird in der hellen sein und nicht auf erden, sonder gebunden in abgrunt der tiefe des hellischen feurs, und die menschen auf erden werden kein ketzerei weiter haben, kein falsch aposteln, kein falsch propheten, kein falsch Christen."

32 Idem, Auslegung des Psalters Davids, II, 7; 99-100: "secht, wie guetig in disem Jerusalem der herr sein wird, daß der schne, der bei uns kalt ist und uns erfroren will und erfroren [sic] und treibt uns ab dem felt, von der gassen in die stuben,- - denselbigen schne will er machen, daß er uns wird sein wie die wollen von schaffen. dieselbigen wollen seindt lind, seindt warm $[. .$.$] also wird auch der schne und der winter hingohn und verloren werden$ [...]. daß also über und über alles gemein sein wird und alles summer”; ibid., 93: “[...] die armen und ellenden worden in Jerusalem mussen frolich sein und werden mit dem harpfen schlagen und singen, [...]"; see also: Goldammer, "Paracelsische Eschatologie," 141-142.

33 Paracelsus, Auslegung des Psalters Davids, II, 7; 93.

34 Paracelsus, in any case, was acquainted with Melchior Spach, the field captain of the 
Paracelsus' expectations were not chiliastic, in the sense that he did not expect a new terrestrial period before the Last Judgement, as if it were an earthly millennium. Like Luther and orthodox Lutherans, his expectations related to the time after Christ's return. But he made matters more elusive by implying that the New Jerusalem will not be a heavenly kingdom at all but rather a terrestrial place, that is, an earthly paradise. After Christ, "the new, golden world will begin, that is [after] this, the final fire from Heaven. There we will live blissfully on earth."35 This world will be the "holy world."36 Luther had claimed that only the past Paradise had been terrestrial, ${ }^{37}$ but Paracelsus suggested that the restored paradise will take place also on earth, meaning that the world will not be destroyed after Christ's Judgement:

[...] God the Lord [will] build a New Jerusalem and will bring all Christians, who today are divided and scattered over the world, together in one Jerusalem, under [the rule of] one Lord, that is under Himself [...]. And once God has pushed the Mammon from the earth, all children of God will live far away from each other, and those He will bring together into one stable, under the rule of one shepherd. This will be the New Jerusalem, which is in this earthly paradise. ${ }^{38}$

rebels of the war in 1525, because the latter was the first listed among Paracelsus' friends in his testament, see: Biegger, 'De Invocatione', 32; Dopsch, "Paracelsus, Salzburg und der Bauernkrieg," 300-306. Paracelsus returned to Salzburg once or twice later in his life; see: Dopsch, "Paracelsus, Salzburg und der Bauernkrieg," 299-308. See also the other articles included in Dopsch and Kramml (eds.), Paracelsus und Salzburg. Like in other German regions, in the preceding years the city's burghers and the peasants had to pay an increasing amount of taxes which, together with religious struggles, resulted in rebellious uprisings throughout the German-speaking lands; see: McClintock and Strong, "Peasants' War," 859. On Paracelsus and the Peasants' War, see: Dopsch, "Paracelsus, Salzburg und der Bauernkrieg," 299-308, esp. 304-306; idem, "Paracelsus, die Reformation und der Bauernkrieg," 201-216.

35 Paracelsus, Auslegung des Psalters, II, 4; 93: "[W]ir danken dir ewiglich und bekennen, daß $\mathrm{du}$, herr, uns erlöst hast, erledigt und erhalten. do wird die neu, guldin welt angehn, das ist dise ... das letzt feur vom himel. do werden wir wonen saliglich auf erden." Based on a comparison of manuscript versions, Goldammer explains in an editorial note that one of the manuscripts, instead of "das ist dise," reads: "das ist nach dise [...]," ("that is after this") which seems correct; see ibid., 93.

36 Ibid., 93: "Als dann so wir seindt in der heiligen welt [...]."

37 On Luther's past earthly paradise, see: Leoni: "Studium simplicitatis: The Letter of Grace in Luther's Commentary on Genesis 1-3," 197-198.

38 Paracelsus, Auslegung des Psalters Davids, II, 7; 90-91: "[...] so wird alsdann got der herr ein neu Jerusalem bauen und wird die christen, so hin und her zerteilt seindt und zerstreuet, zusammen samblen und sie éin Jerusalem bringen, das ist under éin herrn, das 
The incongruous reference to the children of God living far away from each other in a future period was likely intended to refer to the present, rather than the future, where those children who are now separated will be brought together. The New Jerusalem of the Book of Revelation, having already been connected to the millennium, is now also identified with the terrestrial Paradise of the first chapters of Genesis. Such a conception of the last events and the prospect of a new world resembled neither Protestant nor Catholic views, but shares one characteristic with Rosicrucian expectations. The Rosicrucian manifestos describe the imminent earthly improvements as resembling a restored paradise and in this sense as representing a return to the beginning. ${ }^{39}$ Paracelsus, too, suggested such a return of original conditions when he identified the New Jerusalem with the earthly paradise, albeit in his view this return would take place by divine intervention and after Christ's Judgement.

Because Paracelsus believed that history was drawing to a close, also his interpretation of the role of the Antichrist differs from the Rosicrucian description of this apocalyptic figure. In some cases, such as in his On the Secrets of the Secrets of Theology, Paracelsus referred to the Antichrist generally, claiming that all "sects" were Antichrists, because they "call each other the antichrist, which is true," and that each of these sects was recognisable by the fruits of the Antichrist: death and destruction. ${ }^{40}$ In other passages, he specifically placed the Antichrist in the End Times and identified him with Rome. Paracelsus had already argued that in the end of time God will ban the Mammon from the earth. The word "Mammon" originated from the Bible and usually means "money" or "wealth." During the Middle Ages, the term signified a wealthy demon, ${ }^{41}$ but Paracelsus applied this symbolism specifically to the pope. He frequently argued that the Endchrist was to be found in Rome, and he called the pope the "Roman Antichrist." ${ }^{2}$ According to Paracelsus' Sermons on the

ist under sich selbs. [...] so er [Got] den mammon ab der welt hat geton, alsdann werden die kinder gottes weit voneinander wonen, und die wird er zusammen samblen und sie bringen in éin stall, das ist under éin hirten. das wird sein das neu Jerusalem, das ist in disem irdischen Paradeis." The shepherd is, obviously, Christ: Paracelsus, Auslegung der Papstbilder, I, 12; 583: "[...] also wird ein hirt sein, das ist Christus [...]."

39 On this, see above, section 1.2.

40 Paracelsus, De secretis secretorum theologiae, II, 3; 175-176: "[...] wie Rom und andere mehr [...] heißen einander antichristen, ist wahr [...]. Der bapst und die seinen schreien nach dem blut: töt, henk, prinn, ertrink, etc. die andern haben in kurzen jaren vil tausent mann umb ir leben auch bracht, schreien auch: tot, ertrink, etc. das seindt ire frücht, die sie geben, aus denen wir sie erkennen sollen"; idem, Liber de felici liberalitate, NPE 1, 190.

41 Cf. Valenze, Social Life of Money, 95.

42 Gantenbein, "Leben, Tod und Jenseits bei Paracelsus," 188, 19o. Paracelsus often used the term Endchrist; see, for example: NPE 1, 141, 190, 228, 391, 517, 525. Melanchthon also used 
Antichrist, the papal Endchrist will be defeated not by man but by divine intervention, as he will "be expelled from the sheepfold by Christ and should leave it together with his legions." ${ }^{33}$ Christ will defeat the Roman impostor and inaugurate the New Jerusalem on earth. Unlike the manifestos, Paracelsus sided with the pre-Antichrist tradition, according to which the Antichrist comes in the end and is conquered by Christ, after which no new age before the Last Judgement was to be expected - a highly traditional interpretation.

It was fundamental to the Rosicrucian general reformation and their millenarian imagery that the pope could be replaced as ruler over the people, notably by human agency, upon the arrival of the new age. Evidently, in this regard the Rosicrucian authors were not influenced by Paracelsus' eschatology as articulated in his religious texts. For Paracelsus, if the world could not be improved before the Last Judgement, certainly not by human agency, any hope for reform would be in vain simply because there was no earthly time to which one could look forward. When it comes to his conception of history and man's role within it, Paracelsus could not be further from the views later to be expressed in the manifestos: in these religious works, he simply ruled out the possibility of a general reformation.

The authors of the manifestos were presumably unaware of the fact that Paracelsus had expressed these views so divergent from their own, the reason being that his religious works, in which he announced the imminent end and the subsequent earthly paradise, were not easily available at the time when the manifestos were drafted. These works could be found in the collection of Hans Kilian - who kept one of the largest collections of Paracelsian manuscripts in Neuburg - but were never published by Gerard Dorn (1530-1584), Adam von Bodenstein (1528-1577), Michael Toxites (Michael Schütz, 1514-1581), or Johannes Huser (1545-ca. 160o). ${ }^{44}$ These physicians steered clear of Paracelsus'

this term: Oberman, The Reformation, 49. See also: Paracelsus, Sermones de antichristo, $463^{\mathrm{r}}-463^{\mathrm{v}}$, cited in Gantenbein, "Leben, Tod und Jenseits," 189-190; Rudolph, "Theophrast von Hohenheim (Paracelsus). Arzt und Apostel der neuen Kreatur," 36.

43 Paracelsus, Sermones de antichristo, uв Leiden Cod.Vos.Chym. Fols. 25, 461 ${ }^{\mathrm{r}}-4 \mathrm{O}^{\mathrm{v}}$, here 466v: "[...] dass er durch Christum aus dem schafstall ausgetrieben wird und aus demselben weichen muss mit allen seinen legionibus," cited in: Gantenbein, "Leben, Tod und Jenseits bei Paracelsus," 192. Cf. ibid., 190-191. See also: Paracelsus, Sermones de antichristo, $464^{\mathrm{v}}$.

44 On Dorn, see: Kahn, “Les Débuts de Gerard Dorn”; on Bodenstein, see: Gantenbein, “Der frühe Paracelsismus in der Schweiz”; Kühlmann and Telle, Corpus Paracelsisticum, vol. 1, 104-110; on Toxites, see: Schmidt, Michael Schutz genannt Toxites; Sudhoff, "Ein Beitrag zur Bibliographie der Paracelsisten”; Kühlmann and Telle, Corpus Paracelsisticum, vol. 1, 41-66; on Huser, see: Telle, "Johann Huser in seinen Briefen." 
theological writings, not least because the religious views expressed therein had been deemed dangerous and heretical, owing to Paracelsus' criticism of the three rivalling confessions. ${ }^{45}$ This is not to say that they were not read. The Paracelsian physician Alexander von Suchten (ca.1520-1575), for one, was aware of and praised Paracelsus' religious works, while the French alchemist and Paracelsian Bernard Penot (1519-1617) expressed his admiration for Paracelsus' religious conceptions. ${ }^{46}$ But generally, Paracelsus' religious writings, which could circulate only in manuscript form, were far less known in the early seventeenth century than his published medical or philosophical books.

Paracelsus' eschatology as conveyed in these religious works is radically at odds with the Rosicrucian notion of reform, but also with his views expressed in his natural-philosophical works, which offer a more optimistic view of future events. ${ }^{47}$ In his Book on Images, for example, he briefly discussed the numerous sects that had come about since Luther's appearance on the world stage, and explained that "there will come more sects, and each wants to be right, and be better and holier with its teaching than another. And in religion and in the Church there will be no unity and peace, until the golden and final time. But afterwards the Day of the Lord will not be far."48 Clearly, Paracelsus suggested here that a brief, golden, peaceful time may be expected before the end. The terminology is significant, however: the golden world will take place only after the Last Judgement, but a golden time may be expected before Christ's Second Coming.

Paracelsus, moreover, was a medical reformer, and his activities in the fields of medicine and natural philosophy evidently implied that reform, at least in these areas, was possible. In some of his medical and natural-philosophical texts he explicitly announced that his work will prevail over traditional

45 Gilly, "Theophrastia Sancta," 154-158.

46 Von Suchten, $C P$, vol. 1, nr. 31, 553; Penot, Apologiae in duas partes divisa, cited in: Gilly, "Theophrastia Sancta," 158; on Von Suchten, see: Kühlmann and Telle, Corpus Paracelsisticum, vol. I, 545-549. On Paracelsians and religion, against Weber's disenchantmentthesis, see:Webster, "Paracelsus, Paracelsianism, and the Secularization of the Worldview," 9-27.

47 This does not mean that these two types of works, natural-philosophical and religious, were entirely different. On common ground, see especially the works of Dane Daniel, e.g., "Paracelsus' Astronomia Magna." Paracelsus' natural-philosophical and medical works are numerous, an analysis of which is beyond the scope of this study. For relevant literature, see especially: Pagel, Paracelsus; Kahn, "Alchimie et Paracelsisme"; Webster, Paracelsus.

48 Paracelsus, Liber de imaginibus, I, 13; 373: "dan es werden noch mer secten komen, und wird ein ietlicher recht wollen haben, und mit seiner ler besser und heiliger sein, dan der ander. Und wird in der religion und in der kirchen kein vereinigung und frid werden, bis zu der guldinen und lezten zeit. Aber hernach wird der tag des herrn nicht weit sein." 
authorities, that they will remain authoritative until the end of the world, and that all other philosophers should enter his "kingdom." 49 This is best expressed in his Paragranum, where he declared that his medical and scientific contributions will set the rule until the Last Judgement: "Until the last day of the world my writings must remain and genuinely, and yours [the followers of Galen and Avicenna] will be known to be filled with bile, poison and serpents, and abhorred by the people like toads [...]." ${ }^{50} \mathrm{~A}$ few pages later, he added: "[...] the false philosophers will be boiled and tossed into the dung heap, and I and my philosophy will remain. ${ }^{51}$ We will turn to Paracelsus' medical criticism in the following section, but what is striking here is that in Paracelsus' view the dirt left behind by previous physicians and philosophers could be replaced by his own new philosophy. Paracelsus did not specify when exactly this was to happen, but it would in any case occur before the Last Judgement, which further suggests that there will be a future period of earthly improvement established by human beings, that is, in any case, by Paracelsus himself. This view is profoundly different from the eschatological position outlined in his religious writings, but resonates with the Rosicrucian manifestos.

The natural-philosophical works must also have influenced both pseudoParacelsian authors and early Paracelsians. In early seventeenth-century German regions, several authors published their writings in Paracelsus' name. Some of these texts have long been regarded as spurious, while others have only recently been distinguished from Paracelsus' authentic writings. The spurious texts are attributed to pseudo-Paracelsus, although it is most likely that there were multiple authors who abused Paracelsus' name. ${ }^{52}$ The optimistic outlook, in which there was to be another earthly time before the end, was in fact dominant in pseudo-Paracelsian writings. ${ }^{53}$ For example, speaking in the name of Paracelsus and aligning himself with Paracelsus' claims, the author of On the Tincture of the Natural Philosophers claimed that he would continue to lecture his opponents. ${ }^{54}$

49 Cf. below, section 2.3.

50 Paracelsus, Paragranum, I, 8; 200-201: "bis in den lezten tag der welt meine gschriften müssen bleiben und warhaftig, und die euer werden voller gallen, gift und schlangen gezücht erkennet werden und von den leuten gehasset wie der kröten [...]."

51 Ibid., 139: "also werden die falschen philosophi gescheumpt werden und in die mistlachen geworfen, und ich und mein philosophei werden bleiben."

52 Cf. Sudhoff, Bibliographia Paracelsica. On several types of (pseudo-)Paracelsianism, see: Pumfrey, "The Spagyric Art."

53 Cf. the sections below.

54 Pseudo-Paracelsus, De tinctura physicorum, I, 14; 393: "[I]ch werde euch alchimisten und doctors durch mein erlitne arbeit die neu geburt öfnen. Ich werde euch lernen die tinctur, 
The Rosicrucian authors may have been influenced also by the views of several Paracelsians, who had fully accepted Paracelsus' optimistic conception of another earthly age. Presumably inspired by both genuine and pseudepigraphic natural-philosophical writings, they expected a new period on earth to be imminent in which Paracelsus' views would triumph. The Kabbalist, alchemist, and physician to the German Prince Ludwig von Anhalt (1579-1650), Julius Sperber (1540-1616), for example, wrote his On the Three Ages on the eve of the new century (1597). In it, he followed Joachim of Fiore by dividing history into three ages. According to this text, the first age corresponded to the Old Testament and the age of the Father, the second to the New Testament and the age of the Son, "but now the third and last age is approaching," the age of the Holy Spirit. ${ }^{55}$ This third age was understood to be a "golden time." ${ }^{56}$ Sperber referred to the coming period in similar terminology as Paracelsus had used in his Book on Images. He had in mind a period of improvement that was reminiscent of the third age described by Joachim, as it would take place before Christ's Second Coming, like a future millennium. Although the Rosicrucian brethren did not divide history into three ages, their new period resembled Sperber's hopeful expectations.

Like Paracelsus and Sperber, Bodenstein also referred to the new period as a "golden time," and claimed that it was now beginning to take shape on earth. Bodenstein associated the imminence of the new time with contemporary improvements in knowledge: "Long we abided in a time of tittle-tattle, who will deny that now the time of knowledge approaches?"57 Clearly, life on earth had been glum, but better times were on the horizon, in which the arts would thrive. Like the manifestos, he argued that God had already sent messengers to earth so that "from many portents we can learn that changes are imminent $[\ldots] .{ }^{58}$ Soon the world would free itself from the darkness that had cast a shadow over the arts, studies, and places of learning.

die arcana, oder das quantum esse, in welchem alle heimlikeiten, grunt und werk ligt." Sperber, Von den dreyen seculis (1597), 9: "Nunmehr aber ist [...] die dritte und letzte zeit [...] ganz nahe vor der thür." On Joachim of Fiore and the three ages, see: Chapter 1, n. 108.

$5^{6}$ Sperber, Von den dreyen seculis, A8 ${ }^{\mathrm{r}}$ (Vorrede): “[...] Aus welchem nun erscheinet/ daß dieses hohe Geheimnus/ der zeit nach/ nicht ehender als bis auf die ietzige gegenwertige der andern Welt und zeit/ unnd also gegen dem anbrechenden dritten und letzten Seculo/ darinnen solche unsere Seeligkeit und recht Güldene zeit wircklich angehen wird/ [...]." Compare also: ibid., $\mathrm{A}_{4}{ }^{\mathrm{r}}$ and $\mathrm{B}_{7}^{\mathrm{v}}$, where Sperber also wrote of a future golden time.

Bodenstein, $C P$, vol. 1, nr. 7,15 : "Fuimus diù in tempore garriendi, iam tempus sciendi instare quis negabit?"

$5^{8}$ Ibid., nr. 11, 268: "Also hatt Gott der Allmechtig inn gegenwertiger güldinen zeyt/ da das Wort Gottes hell an tag/ dergleychen alle güte Künsten so herrlich herfür gebracht werden [...]"; ibid., nr. 7, 154: "Signis multis discere possumus instare mutationes [...]." 
These Paracelsians adopted and emphasised the more optimistic, but generally less explicitly apocalyptic views of earthly improvement of Paracelsus. In their apocalyptic visions, the Rosicrucian manifestos were possibly not inspired by Paracelsus' religious works, but aligned with his medical and naturalphilosophical views, and more so with the views of some of his successors.

\subsection{The Revelation of Secrets}

That the manifestos have more in common with some early Paracelsians than with Paracelsus' own religious texts can also be concluded from their apocalyptic views. According to the Rosicrucian manifestos, the changes of the new age could already be espied through the portents God had placed in nature and heaven for humans to decipher His secrets. In historiography, revelation is referred to by the terms "apocalyptic" and "apocalypticism." "Apocalyptic" is the belief that all things will be revealed during the Last Days of the world. This was the way Paracelsus interpreted revelation, who had declared in his book on elemental beings, the Book on Nymphs, Sylphs, Pigmies and Salamanders and other Spirits (date unknown), about the final time that "[n]ow is the time, that things will be revealed"; explaining in his Prologue on the Blessed Life (1533?) that " $[\mathrm{t}]$ his will come to light, which God wants to be brought to light. And now is the time, and summer is drawing close." ${ }^{\prime 59}$ These revelationary phrases refer to the time shortly before the Last Judgement, because Paracelsus had used the word "summer" to indicate the New Jerusalem. Although he described this period by means of a natural analogy rather than by reference to the Book of Daniel, the moment of revelation, shortly before Christ's second Coming, is traditional.

The more general notion of "apocalypticism" refers to divine revelations generally, and not specifically during the Last Days. In this way it was used not only in the Rosicrucian manifestos, but also by early Paracelsians. The Paracelsian physician Michael Toxites claimed, in the preface to his edition of Paracelsus' Philosophia Sagax, or Great Astronomy (1571), that

On the revelation of God's secrets in this time, see also: $C P$, vol. 1, nr. 6, 121-122; $C P$, vol. 1 , nr. $7,163-165$. Bodenstein was not solely optimistic about ancient divine wisdom, and just like the manifestos he recognised the important scientific contributions that had occured since ancient times.

59 Paracelsus, Liber de nymphis, I, 14; 149: “Iezt is die zeit, das offenbar sol werden [...]"; idem, Prologus in vitam Beatam, II, Suppl.; 3: "also kombt das an tag, das gott an tag haben will. Dan ietz ist die zeit, und der sommer nahent herzu." For an English translation of the Liber de nymphis, see: Paracelsus, Four Treatises, 223-254. 
man is created for that purpose, that in flesh and blood he is an appropriate instrument of the natural light, through which God reveals all secrets of the heavens, the elements, and all of nature in all sorts of arts and wisdom, so that the invisible will become visible, which will not occur without human beings. ${ }^{60}$

Inspired by the light of nature, human beings can study and comprehend the natural world and all treasures hidden within it, so that all heavenly and natural secrets will be revealed not by Christ but by human agency in accordance with God's plan. For Toxites, the renovation of the arts would not just free the world of age-old authorities, but was specifically set in motion by God to finally bring to light the secrets of His creation.

Bodenstein was another Paracelsian author who believed that secret wisdom will be revealed with the coming of the new age. He maintained that nothing will remain hidden, invoking a proverbial analogy that would surely have appealed to the Rosicrucians: "[ $\mathrm{t}]$ he time brings forth roses." ${ }^{61}$ As a Paracelsian physician, he believed that the new time would coincide specifically with the revelation of a "heavenly medicine." This medicine was a gift from God against sinful activities and for the conversion of non-Christians, specifically Jews, Tartars, and Turks. ${ }^{62}$ Bodenstein argued, in line with the philosophia perennis, that "the restoration of medicine occurs in our times."63 The perfect medicine, he

6o Toxites, preface to Astronomia Magna, Avv: "So ist nun zu wissen/ daß der Mensch darumb erschaffen/ daß er in Fleisch und Blut were ein geschickts Instrument des natürlichen Liechts/ dardurch Gott alle heimligkeiten offenbar machte des gestirns/ des Element/ und der ganzen Natur in allerley Künsten/ und Weißheiten/ damit das unsichtbar sichtbar würde/ welches ohn den Menschen nicht beschehen were."

61 Bodenstein, $C P$, vol. 1, nr. 7, 154: "Nihil enim teste spiritu sancto adeo reconditum est, vt non reueletur, et nihil adeo occultum, quod non sciatur. Ideo nos trito prouerbio dicimus, Tempus proferre rosas."

62 Ibid., 152: "Verum medicina est res sancta et Dei munus, Quod medius fidius extra Ecclesiam apud Turcas, validos osores Christi, Iudaeos perfidos, Tartaros, aliosque veri numinis irrisores non magis quaerendum, quam in Ecclesia est, propter quam aeterna medicina descendit ex coelo, eamque curauit." Cf. ibid.: "Cogitemus omnes morbos omnemque mortem esse peccati poenam, quam nemo potest mitigare, longe minus totam auertere, nisi fuerit instructus excellenti aliqua re à Deo tradita: Quemadmodum enim Christus verus Dei filius nos redemit ab aeternis morbis, sic oportet medicum, corporis morbos arcere et curare, quousque tempus dissolutionis veniat, quod certe non fieri potest absque coelesti medicina, quam Deus firmam, certam et efficacem donat suis contra peccati operationes, quo agnoscamus per eam longe diuiniorem medicinam, eique respondeat nostra."

63 Ibid., 154: "Quapropter eximie vir, non est mirum, si medicinae fiat restauratio hisce nostris temporibus, quibus Deus sempiterna lux mira reuelat. Quia ipsi displicent hominis terreni figmenta, sua autem bona, quae sunt certa ac sancta, amat et manifestari cupit." 
claimed, was bestowed by God on the first human beings; it was perfectly practiced before Hippocrates; traces of it had been found by Hermes Trismegistus, and it had been disclosed through the alchemical Emerald Tablet. It had afterwards been lost-but humans were now once again granted access to such perfect medicine. ${ }^{64}$ Bodenstein gave a medicinal reading of this text: the Tablet states that all things come from one, and Bodenstein's inference was that this perfect medicine came from one, that is, from God. This medicine and the perfect wisdom associated with it were granted by God through divine illumination before the end, as a restoration or instauration of what had once been lost. Similar beliefs are reflected in the Rosicrucian notion of a general reformation and the brethren's belief that the new time would see original perfection and wisdom restored.

\section{Apocalyptic Alchemy}

In the manifestos, divine revelations at the dawn of the new age are associated with alchemy, an art practiced by Christian Rosencreutz that might be deployed to its full potential in a bid to transform the world. ${ }^{65}$ Usually, alchemy was seen as a means to purify and perfect nature, whether in order to find the philosophers' stone or in the form of chrysopoeia, the art of transmuting metals into gold. The latter as a legitimate reason for the practice of alchemy was especially rejected by the authors of the Rosicrucian manifestos:

Concerning the godless and accursed making of gold in our times especially, it has gotten so out of hand, that it has induced first of all many wayward gallows-bound sycophants to practice great mischief under its name, and to abuse the curiosity and credulity of many [...], as if the alteration of metals were the highest apex and summa in philosophy [...] ${ }^{66}$

64 Ibid., 151: "Eodem sane modo medicina verum Dei munus saepius mutationes sensit: Quia mundi IEHOVA primis hominibus, qui naturaliter vixerunt, maximam naturae cognitionem cum longa vita est largitus, Caeterum peccato nimium paulatim crescente, usque adeo ignorantia successit scientiae, tenebrae luci, vt Dominus non solum homines morbis affligeret [...]. Hermes quidem dicitur postea duas lapideas tabulas reperisse, in quibus veteris medicinae et totius naturalis scientiae vestigia restabant, sed ars vera, nec illic erat inscripta, nec homines eam à Noe alijsqui recte didicerunt"; ibid.: "[...] Ex hisce liquet medicinam ante Hyppocratem fuisse, et syncerius tractatam, quam vulgus medicorum ipsius aetate declararit."

65 Fama, 102.

66 Ibid., 124-125: "Was aber sonderlich zu unser zeit, das gottloß und verfluchte Goldmachen belangt, so sehr überhand genommen, daß zuforderst vielen verlauffenen henckermässigen Leckern, grosse Büberey hierunter zutreiben, und vieler fürwiz und Credulitet sich 
The Rosicrucians understood alchemy to be a part of philosophy, but transmutational alchemy, that is, alchemy used for the amelioration of base metals (e.g., lead, tin, copper, iron) into noble metals (silver and gold) was not among their foremost studies. The manifestos claimed that many books and pictures had been published "in the name of Chymia" which were "an offence to the glory of God." ${ }^{n 7}$ Alchemy was a divine art whose value was not to be diminished through the use of images or by using it to make gold. Most books published on the subject were false and filled with recipes of fake tinctures. ${ }^{68}$ In this context, the Confessio alluded to the Amphitheatrum of the alchemist and theosopher Heinrich Khunrath (156o-1605), a work on alchemy which the Rosicrucians seem to have reviled for its images and figures. ${ }^{69}$

With these views, the Rosicrucians implicitly rejected some of the practices of Paracelsus and his followers. ${ }^{70}$ Paracelsus, as an alchemical physician, had of course used alchemy primarily for medical purposes, but he had not always distanced himself from transmutational alchemy and chrysopoeia. In his Book on Renovation and Restoration, he discussed the restoration and renovation of metals, minerals, and the human body. ${ }^{71}$ His On Minerals describes the use of alchemy for the transmutation of metals and supports that practice. ${ }^{72}$ Alchemists and physicians, in his view, had the possibility to transform and purify elements and metals (transmutational alchemy) as well as human bodies (medical alchemy), involving sometimes the same minerals, such as antimony. ${ }^{73}$ Nevertheless, discussions of transmutational alchemy are rare within his writings,

mißzubrauchen anleytung geben [...] als ob die mutatio metallorum der höchste apex und fastigium in der Philosophia were [...]."

67 Ibid., 126: "Wir bezeugen auch, daß unter den Chymischen Nahmen sein Bücher und Figuren außkommen, in Contumeliam gloriae Dei."

68 Confessio, 6o-61; Confessio (Gdańsk), 79.

69 Confessio, 6o-61: "In fine verò confessionis nostrae illud seriò inculcamus, abjiciendos esse, si non omnes, plerosque tamen pseudochymicorum nequam 1 bellos [sic]; quibus vel SS. Triade ad futilia abuti lusus: vel monstrosis figuris atque aenigmatibus homines decipere jocus: vel credulorum curiositas lucrum est: qualis aetas nostra plurimos produxit: unum ex ijs praecipuum Amphitheatralem histrionem, hominem ad imponendum satis ingeniosum”; cf.: Confessio (Gdańsk), 79. On Khunrath, see: Forshaw, “Paradoxes, Absurdities, and Madness."

70 On Paracelsus and transmutation, see the articles included in the special issue of Ambix, vol. 67 (2020), Paracelsus, Forgeries and Transmutation, edited by Didier Kahn and Hiro Hirai.

71 Paracelsus, Liber de renovatione et restauratione, I, 3; 203-221.

72 Paracelsus, De mineralibus, I, 3; 32. See also: idem, De transmutationibus metallorum, I, 3; 69-88.

73 Two examples in this regard are: Paracelsus, Volumen Paramirum, I, 1; 165-239; and idem, Opus Paramirum, I, 9; 39-230. 
and more often than not he distanced himself from it, arguing instead for the benefits of alchemy for the restoration of the human body and the pursuit of longevity.

To muddy the waters even more concerning Paracelsus' attitude towards chrysopoeia, some spurious works published under his name dealt approvingly with the transmutation of metals. The Alchemical Treasure, On the Nature of Things, and the Book of Vexations, for example, all dealt with and promoted transmutation. ${ }^{74}$ The author of the equally spurious On the Tincture of the Natural Philosophers described two types of what he called "spagyric mystery," namely the renovation of the body and the transmutation of metals. ${ }^{75}$ All of these works were taken as genuine by Huser, and some of them had been published by Bodenstein, Toxites, and Dorn. ${ }^{76}$ These Paracelsians, too, practiced alchemy and wrote about the transmutation of metals. ${ }^{77}$ Dorn, Von Suchten, and Leonard Thurneysser (1531-ca. 1595), who were involved in the dissemination of Paracelsus' works, worked not only on Paracelsian medicine but also on transmutational alchemy. ${ }^{78}$ According to Sperber, finally, the philosophers' stone could be used both for the advantage of medicine as well as for the transmutation of metals. ${ }^{79}$ All Paracelsians, however, preferred chymiatria

74 Pseudo-Paracelsus, De natura rerum, I, 11; 309-403; idem, Thesaurus 〈Thesaurorum〉 Alchemistarum, I, 14; 401-404; idem, Coelum philosophorum sive liber vexationum, I, 14; 405-420. Cf. Telle, “'Vom Stein der Weisen'."

75 Paracelsus, De tinctura physicorum, I, 14; 391-399, esp. p. 397.

76 On this, see: Sudhoff, Bibliographia Paracelsica: for Manuale de lapide philosophico medicinali, 235, 268, 394; for Liber vexationum, 257, 393; for Thesaurus Alchimistarum, 257, 268, 343, 393; for De natura rerum, 345, 392. Other works include: De vita longa: ibid., 392; De tinctura physicorum: ibid., 189-19o, 235, 268, 392, and Sudhoff, Sämtliche Werke, I, 14; xiixvi.

77 On Paracelsianism and alchemy, see: Morys, "Leonhard Thurneissers De transmutatione veneris in solem"; Telle, "'vom Stein der Weisen"; Paulus, "Alchemie und Paracelsismus um 16oo"; Kahn, "Les débuts de Gérard Dorn"; idem, Alchemie et Paracelsisme; idem, Le fixe et le volatil; Kühlmann and Telle, Corpus Paracelsisticum, II, 823-829; Newman and Principe, Alchemy Tried in the Fire, 50-56; Principe, The Secrets of Alchemy. See further: Moran, The Alchemical World of the German Court; Shackelford, A Philosophical Path for Paracelsian Medicine.

78 See, for example: Dorn, Clavis totius philosophiae chymisticae (1567); idem, Congeries paracelsicae chemiae de transmutationibus metallorum, 557-646; Von Suchten, De secretis antimonii; idem, Tractatus secundus de antimonio vulgari (1604); Thurneysser, De transmutatione veneris in solem. On the latter text, see: Morys, "Leonhard Thurneissers De transmutatione veneris in solem." On Von Suchten: Newman and Principe, Alchemy Tried in the Fire, $5^{\mathrm{o}-56 \text {. }}$

79 Sperber, Von den dreyen seculis, 206-209: "Auch wie man den verum lapidem Philosophorum so woll zur transmutation der Metallen/ als auch zur Arzteney warhafftig und beständig machen möge." 
(alchemical medicine) over chrysopoeia. By the time the manifestos were drafted, Paracelsus could therefore also have been seen as an alchemist involved with transmutation, with the transmutational art being promoted not only by the master himself, but also by some of his followers and imitators. But the Paracelsian texts explicitly concerned with chrysopoeia had not left their mark on the Rosicrucian manifestos.

The Rosicrucian authors made transmutational alchemy subordinate not to medical alchemy, but to what may be called "apocalyptic alchemy," that is, to a type of alchemy used for the disclosure and revelation of secrets. ${ }^{80}$ Transmutational alchemy was not entirely dismissed, but was viewed rather as a parergon, a secondary activity. According to the Fama, many alchemists falsely maintained that the making of gold should please God, but:

We hereby declare publicly that this is false, and that for the true philosophers it is a trifle and only a secondary activity. Together with our beloved Father C.R.C. we say: 'pfuh, gold is just gold.' So he to whom all of nature has been opened, does not rejoice in that he can make gold, or as Christ says, that the devils obey him, but that he sees heaven to be open, and the angels of God ascending and descending, and his name written in the Book of Life. ${ }^{81}$

While the transmutation of metals was not to be abandoned altogether, neither was it promoted, and emphasis was put, instead, on the study of nature and heaven, and the revelation of natural and divine secrets on the eve of a new age through alchemy. For the Rosicrucians, alchemy should not be practiced for the mundane benefits it might provide; its purifying capacities were used for apocalyptic purposes. As such, alchemy had theosophical characteristics, as it was,

8o On apocalyptic alchemy in a very different, notably female, alchemist, see: Nummedal, Anna Zieglerin, 135-136. This terminology is also employed by DeVun and applied to the works of Rupescissa and Arnald of Villanova: DeVun, Prophecy, Alchemy and the End of Time, $57 \mathrm{ff}$.; and the notion is studied and termed "prophetic alchemy" or "concrete prophecy" in: Crisciani, "Opus and Sermo," 4. See also: Murase, "Paracelsismus und Chiliasmus."

81 Fama, 125-126: "So bezugen wir hiermit öffentlich daß solches falsch und es mit den wahren Philosophis ein geringes und nur ein parergon ist [...]. Und sagen mit unserm lieben Vatter C.R.C. Pfuh aurum, nisi quantum aurum, dann welchem die gantze Natur offen, der frewt sich nicht das er gold machen kan, oder wie Christus sagt, ihme die Teufel gehorsam seyen, sondern daß er siehet den Himmel offen, und die Engel Gottes auff und absteigen, und sein Nahmen angeschrieben im Buch des Lebens." 
ideally, a means to revealing natural and divine miracles and secrets-which is why apocalyptic alchemy played a singular role in the Rosicrucian general reformation. ${ }^{82}$

Attributing to alchemy these apocalyptic properties was not at odds with the literature of the time. The transformation of nature was sometimes related to salvation through Christ and to an understanding of soteriology, wherein the philosophers' stone was sometimes identified with Christ. ${ }^{83}$ Alchemy was seen as a means to reveal what was hidden and to prophesy upon what was still unknown. In the same vein, the authors of the manifestos stated that through their alchemical practices they could push their observations beyond the borders of the material world and see the movements of God's angels in imitation of Jacob's Ladder from Genesis, ${ }^{84}$ and they could read and understand the names written on the Book of Life, that is, the names of those who will be saved during the Last Judgement. ${ }^{85}$ Through their art, the Rosicrucians had singular access to secret and sacred matters. Thus the Confessio reads that this art is "the highest medicine of the world," it is "a gift from God," and it "opens [medicine] and innumerable other marvels" - even if it would be preferable to achieve these things through philosophy. ${ }^{86}$ By means of apocalyptic alchemy, alchemists could obtain insights into the secrets hidden in nature and in the heavens.

82 Confessio, $5^{8-59 .}$

83 Crisciani, "Opus and Sermo," 21-22; Nummedal, Anna Zieglerin, 134. On the philosophers' stone, see: Principe, The Aspiring Adept, 76-80; idem, The secrets of Alchemy; Newman and Principe, Alchemy Tried in the Fire; Nummedal, Alchemy and Authority, 96-118. For Paracelsus and several Paracelsians on the philosophers' stone, see: Paracelsus, Archidoxa, cited in: Khülmann and Telle, $C P$, vol. 1, 131; Bodenstein, $C P$, vol. 1, nr. 6, 114; pseudoParacelsus, Apocalypsis Hermetis, edited by Zetzner (16o3), part 2, 668-671; pseudo-Paracelsus, De tinctura physicorum, I, 14; 391-399; Sperber, Von den dreyen seculis, 206-209. The philosophers' stone, in these writings, does not seem to have been understood as Christ, which was however not an uncommon identification at the time; see, for example: Jung, Psychologie und Alchemie, "Die Lapis-Christus-Parallele," 395-491.

84 Genesis 28:12: "And he dreamed, and behold a ladder set up on the earth, and the top of it reached to heaven: and behold the angels of God ascending and descending on it."

85 Cf. Book of Revelation 2o. The Formula of Concord, however, reads: "Verbum autem Dei deducit nos ad Christum, is est liber ille vitae": Lietzman (ed.), "Konkordienformel," in Die Bekenntnisschriften der evangelischen-lutherischen Kirche (1952), 817. This is repeated on ibid., 1068.

86 Confessio, 58-59: "Quae porro cum Impostorum detestatione contra metallorum Transformationem, et supremam Mundi medicinam a nobis dicta sunt, ea sic volumus intelligi, Nullo modo extenuari a nobis tam insigne Dei donum: sed cum non perpetuo Naturae cognitionem secum afferat, haec vero \& illam \& infinita alia Naturae miracula edoceat, aequum est, potiorem a nobis philosophiae cognitionis rationem haberi [...]." 


\section{Christian Rosencreutz, Elias, and Paracelsus}

With respect to the disclosure of secrets, a striking similarity can be observed between the protagonist of the Rosicrucian manifestos, Christian Rosencreutz, Paracelsus, and the hero of early modern Paracelsian alchemists and physicians, Elias Artista. ${ }^{87}$ Christian Rosencreutz was described as someone who had begun his brotherhood in order to pass on the secrets he had learned elsewhere. When his vault was rediscovered, notably at a time when all hidden things were said to come to light, the treasures buried together with Christian Rosencreutz were also opened. ${ }^{88}$

For several early Paracelsians, the use of apocalyptic alchemy upon the arrival of the new age became associated with a newly invented apocalyptic figure, Elias Artista. This figure was to disclose all divine mysteries on the eve of the millennium or else of a new period defined otherwise. ${ }^{89}$ This "Elijah the Artist" was heralded especially by physicians, chemists, and alchemists, and their expectations were often associated with a sense of scientific or cognitive progress.

The legendary Elias Artista was a derivative of the prophet Elijah who, in the Jewish and Christian traditions, was thought to return again and reveal all secrets. Elijah had returned to the kingdom of God without having died (2 Kings 2:1-18). Since he had not died, he was believed not to be resurrected after the Last Judgement. As a consequence, Elijah became an eschatological figure who was expected to return before the end of time to reveal all wisdom which he had learned while residing with God. ${ }^{90}$ This notion of Elijah as the harbinger of wisdom had its origin in the Jewish rabbinic tradition, where rabbis discussed the true meaning of Scripture and waited for Elijah to reveal the true answers. Paracelsus had also referred to the coming of Elijah, albeit sporadically, but he never added the title "Artista." It therefore seems that he referred to the traditional eschatological figure, although he did associate Elijah particularly

87 On Elias Artista, see: Pagel, "The Paracelsian Elias Artista and the Alchemical Tradition"; Breger, “Elias Artista”; Gilly, “Johann Arndt und die ‘dritte Reformation'”; idem, “Der 'Löwe von Mitternacht."

88 Fama, 116-117. On the vault, see below, section 2.4.

89 For several Paracelsians and their references to Elias Artista, see: Murase, "Paracelsismus und Chiliasmus."

90 Breger, "Elias Artista," 50-53. Pagel identifies this messianic figure with a medieval Franciscan monk named Helias, and claims that the Elias Artista figure had medieval roots. This thesis seems farfetched, and Pagel provides no evidence of any medieval author referring to "Elias Artista," see: Pagel, "The Paracelsian Elias Artista," 9-10. On criticism of Pagel's suggestion, see also: Gilly, “Johann Arndt," 63-64. 
with alchemy. ${ }^{91}$ Julius Sperber, who likewise never referred to an Elias Artista, also announced the imminent arrival of Elijah. According to him, the traditional eschatological figure was to return at the beginning of the third earthly age. While Moses had announced the first age, and Christ the second, Sperber explained, "the prophet Elijah, who will return then, will initiate the third and last age."92

Other Paracelsians believed that it was Elias Artista who would reveal all secrets and, following Paracelsus' interpretation of the prophet Elijah, would do so primarily through alchemy. Pseudo-Paracelsus, in On the Tincture of the Natural Philosophers, mentioned the apocalyptic Elias Artista as the one "who will disclose the concealed."93 After its first publication in 1570 this text circulated widely. ${ }^{94}$ It was in the possession of Toxites and Von Suchten, both of whom took it to be a genuine work. Von Suchten predicted that "the contents of [the books of the Magi about alchemy] will remain hidden, until Elias Artista comes, and explains it to us." ${ }^{95}$ Dorn also knew On the Tincture, which he translated into Latin in $1570 .{ }^{96}$ In 1581, he published a Collection of Paracelsian Chemical Texts on the Transmutation of Metals, which was printed again in 1602 in the first of the six volumes of the Theatrum Chemicum (Chemical Theatre)

91 Paracelsus, Von den natürlichen Dingen, I, 2; 163: "nun aber eisen in kupfer zu machen, ist nicht so vil, als eisen in golt zu machen. darumb das weniger letzt got offenbar werden, das merer ist noch verborgen, bis auf die zeit der kunst Helias, so er komen wird."

92 Sperber, Von den dreyen seculis, 19: "Die dritte und letzte zeit aber wird anfahen der Prophet Elias/ welcher alsdan wiederkommen wird."

93 Pseudo-Paracelsus, De tinctura physicorum, I, 14; 396: "[...] dan diser arcanorum, welche die transformations geben, sind noch mer, wiewol wenigen bekant. und ob sie schon einem von got eröffnet werden, so bricht doch der rum der kunst nit also von stund an herfür. Sonder der almechtig gibt im auch den verstant gleich mit, die selbigen andern zu verhalten bis auf die zukunft Heliae artistae, da das verborgen wird offenbar werden."

94 Sudhoff, Sämtliche Werke, I, 14; xii-xvi. Von Suchten, however, thought that the present times were the last ones: Von Suchten, $c P$, vol. 1, nr. 33, 573-574.

95 Von Suchten, Mysteria gemina antimonii, 92: "Also haben die Magi viel Bücher davon [transmutation] geschrieben/ und ein jeder nach seines Herzen Luft dasselbig tractirt/ wir haben der Bücher viel/ sind gemein worden. Aber ihr Innhalt bleibet verbogen/ so lang biß Helias Artista kommt/ und uns dieselbigen auslegt." For the Magi in Paracelsus, compare: Paracelsus, Aus der Philosophia super Esaiam, I, 12; 507; idem, Astronomia Magna, I, 12; 27, 83-85, 125, 278, 370; Webster, Paracelsus, 67n42-43. Paracelsus seems to turn from the Persian and Egyptian magi to the Magi of the Orient, who witnessed Christ's birth in Bethlehem.

96 Dorn, Archidoxorum Aureoli Ph. Theophrasti Paracelsi de secretis naturae mysteriis libri decem, 253-170. 
published by Lazarus Zetzner (1551-1616), who was later also to publish the Chemical Wedding. ${ }^{97}$ In the Collection, Dorn discussed a tincture of the philosophers, and copied and translated the entire passage on Elias Artista from $\mathrm{On}$ the Tincture. ${ }^{98}$ According to him, until Elias' arrival all (alchemical) secrets will remain hidden. 99

The Paracelsian Toxites, in a 1574 letter to Count Palatine Philip Ludwig of Neuburg (1547-1614), claimed that Elias Artista will reveal all mysteries upon the dawning of the new time: "[...] the time has come, that God will reveal everything. Then God the Lord will let us be handed the books, and He wants us to commit to them, and to search [in them], until He sends us Elias Artista, who will explain everything [...]."100

In a letter of 1571 to Archduke Ferdinand II (1529-1595), Bodenstein invested a new meaning into the figure of Elias Artista by identifying him with Paracelsus, who had revealed all secrets, especially with respect to "studies in medical, metallical, yes, all philosophical things." Some had tried to obscure his work, but his books were "mighty" and teach "how all external and internal pains and diseases can be stilled and cured." 101 For Bodenstein, it was Paracelsus who had at last brought to light all that was hidden and that would serve as the basis for the new golden time.

97 Idem, Congeries Paracelsicae Chemiae (1581), reprinted in: Theatrum Chemicum (1602), $557-646$.

98 Dorn, Congeries Paracelsicae Chemiae, 610: "Arcana plura transmutationes exhibentia reperiuntur, et si paucis cognita, quae licet alicui manifestentur à Domino Deo, non propterea statim erumpit rumor cum arte, sed omnipotens cum ipsis dat pariter intellectum haec \& alia celandi usque in aduentum Heliae Artistae, quo tempore nihil tam occultum quod non reuelabitur."

99 Ibid., 626. Other passages are also used by Dorn, compare ibid., 6o8-6o9, and PseudoParacelsus, De tinctura physicorum, I, 4; 395-397.

100 Toxites, $C P$, vol. 2, nr. 52, 281: “[...] das die zeit vorhanden/ da es alles offenbar werden sol. Dann laßt vns Got der Herr die Bücher zuhanden kummen/ so will er auch das wir vns darinn vben/ vnnd suchen/ biß er vns den Eliam artistam gar zuschicket/ der alles wirt erklären [...]."

101 Bodenstein, $C P$, vol. 1, nr. 23, 46o: "Dvrchleuchtigster/ hochgeborner Fürst gnedigster Herr/ dieweil Aureoli Paracelsi/ Helie artiste lucubrationes in re medica/ metallica/ ja aller philosophia/ wie ers in seinem irdischen leben geweissaget/ fein ein andern nach offenbaret werden/ wol aber etwann von wenigern in solchen sachen/ verstandigern/ die dann vonn wegen des hartleßlichen schreibens Theophrasti nicht allein den buchstaben/ sonders den rechten innhalt verduncklen vnnd obscurieren thun/ vnnd aber ann mich gereicht/ diese gegenwirtigen libri metamorphoseon/ so also großmechtig im werck warlich seind/ das ich inn der welt meine tag keine bücher gelesen (ausserthalb Göttlicher) so diesen vergliechen können werden/ Weil jhr begriff lehrnet/ alle eusserliche vvnd innerliche schmertzen vnd kranckheit zü stillen/zü medieren [...]." 
This apocalyptic task of Paracelsus was also mentioned in the manifestos. When in the Fama the brethren referred to the Fiery Trigon, the new cycle of conjunctions taking place in the three fire signs (Aries, Leo, and Sagittarius), they also made reference to some heroes exemplary of the new time it announced, among whom was Paracelsus. ${ }^{102}$ Paracelsus was thus explicitly mentioned as one of the men who had revealed and announced imminent changes, and was thereby seen to have played a role similar to that of the Elias Artista of the Paracelsians as well as to that of Christian Rosencreutz.

\subsection{Alchemy and Medicine}

The famous physician Paracelsus and the legendary figure Christian Rosencreutz share further profound resemblances, as uncovered by further examination of the alchemical and medical influence of Paracelsus on the manifestos. Like the interpretations of Elias Artista, both Paracelsus and Christian Rosencreutz originated from German-speaking regions, and both men were acquainted with medicine. Paracelsus is primarily known as a physician, but the protagonist of the Rosicrucian manifestos was also acquainted with the healing arts, which he had practiced while in Damascus among the Turks and which he used to prevent diseases in other people. ${ }^{103}$ Together with the first brethren of the fraternity, he agreed that the only profession they would practice was medicine. "Most of the brethren," according to the Fama, "were known and praised among very old people due to their medicine." 104 These brethren seem to have been able to prolong life, using their medicine for rejuvenation.

Both Paracelsus and Christian Rosencreutz had also travelled widely. Throughout his career, Paracelsus had travelled through Europe as a surgeon and physician. He claimed to have worked as a military surgeon in six different

\footnotetext{
102 Fama, 100-101. See further below, section 2.4.

103 Fama, 94: "[Fr. C.R.] zohe auff Damascum zu/ willens/ von dannen Jerusalem zubesuchen/ als er aber wegen Leibes beschwerlichkeit alldar verharren/ und wegen des Artzneyens (dessen er nicht ohnbericht war) der Türcken Gunst erhielte [...]"; ibid., 118-119.

104 Ibid., 120: "Sein also schon damahln Pr. O. und Pr. D. verschieden gewesen, wo ist nun ihr Begräbnuß zufinden? Uns zweiffelt aber gar nicht, es werde der alt Bruder senior, als etwas besonders zur Erden gelegt, oder veilleicht auch verborgen worden sein: Wihr verhoffen auch, es sol diß unser Exempel andere erwecken, fleissiger ihre Nahmen, die wir darumben eröffnet, nachzufragen, und dero Begräbnuß nach zusuchen, dann der mehrertheil wegen der Medicin noch unter uhralten Leuten bekandt und gerühmet werden [...]." Cf. ibid., 96, 106.
} 
countries, and to have medical experience from at least twelve. ${ }^{105}$ Especially after he was forced out of Basel, Paracelsus wandered from place to place, practicing his medicine and preaching his sermons. Rosencreutz, in turn, travelled widely through the Arab world, and studied subjects that were not taught in European regions. He afterwards promoted them in European lands, andperhaps in parallel with Paracelsus' medical reformation - they formed the basis of his project of general reformation which he later initiated in Germany. ${ }^{106}$

But the likeness between the two men extends beyond such bibliographical similarities. The knowledge Rosencreutz acquired in Damcar and Fez became the foundation for his fraternity. Paracelsus, too, shares similarities with Arab sources. Like other alchemists, he drew on the Mercury-Sulphur dichotomy of medieval Islamic alchemy, although he adapted it to his own medical purposes within his own reform programme. He amended this dichotomy by adding salt so as to form the tria prima of Mercury (with liquid or fluid characteristics), Sulphur (oily or fiery), and Salt (alkaline or solid). ${ }^{107}$ Salt was also discussed in Arab texts, but there and in texts of the European Middle Ages it was not added to the dichotomy. ${ }^{108}$ For example, the famous but spurious Arab Book on Alums and Salts was written in the name of Muhammad ibn Zakaryya al-Rāzì (ca. 853925). This text deals with several types of salt, and had acquired enormous popularity during the Middle Ages and in the early modern period. ${ }^{109} \mathrm{Al}$-Rāzī was criticised by Paracelsus on numerous occasions, as was Avicenna, for example in relation to the Mercury-Sulphur dichotomy. ${ }^{110}$

Paracelsus further understood his tria prima first and foremost as principles rather than elements or minerals, and he believed that every thing and every body consisted of these principles in different combinations. Against the ancient philosophers and their followers, he wrote:

105 On his travels, see: Paracelsus, Spital Buch, I, 7; 374-375; Paracelsus, Grosse Wundarznei, I, 10; 19-20. For doubts on Paracelsus' journeys, see: Crone, Paracelsus: The Man Who Defied Medicine, $38-40$.

106 Fama, 94-98, 118.

107 On the diverse meanings that Paracelsus attributed to these three principles, see:Webster, Paracelsus, 132-139.

108 On the medieval Sulphur-Mercury dichotomy, see: Principe, The Secrets of Alchemy, 35-37, $5^{6-58 .}$

109 Al-Rāzī, Liber de aluminibus et salibus, discussed in: Newman and Principe, Alchemy Tried in the Fire, 39-40.

110 See, for example: Paracelsus, Paragranum, I, 8; 137-138, 147-149; idem, Paragranum, in Weeks, Paracelsus: Essential Writings, 74, 232; idem, Von der Französischen Krankheit, I, 7; 172-173. Paracelsus evidently also criticised Greek and Latin scholars in this respect. 
Now notice in this: they say after the ancient philosophical teaching that from mercury and sulphur all metals grow, and that similarly no stone grows from clean soil. Now, what lies! What should be the cause for which the matter of the metals should be solely sulphur and mercury, while the metals and all mineral things consist of three things and not of two? 111

The doctrine of the tria prima was also relevant to Paracelsus' medicine, which was based on alchemically prepared cures. According to Paracelsus, every individual body has in it a minor alchemist, a so-called "archeus," seated in the stomach with several sub-archei in every organ, which were responsible for separating the pure from the impure. Medicine, he thought, should work similarly, and should separate the pure from the impure when the archeus cannot effect this separation on its own. In analogy with the alchemical worker within humans, also physicians should proceed alchemically. When bad influences enter the body (invasion and contagion), and the archeus cannot work properly so that a person becomes sick, a physician should apply a chemically prepared cure which has to correspond to the disease in order to cure the body. ${ }^{112}$ Because medicines could also be extracted from poisonous substances, which was a radical claim at the time, medicines had to be chemically prepared and purified and then applied in a most minimal dosage as remedies to the ill person. The famous term spagyria is applicable here, which originates from the Greek words span (to draw out) and ageirein (to bring together), and was used to designate this specific Paracelsian type of medicine. ${ }^{113}$ Paracelsus, indeed, advocated the separation and recombination of medicines-to-be, such as herbs and minerals. He was very clear about the use of alchemy for medicines: “[...] because in the arcana [here: 'secret' or 'hidden' medicines] lies the determining factor, the foundation must be alchemy, through which the arcana can be prepared and made."114 And it is "not, as they say, that alchemy

111 Paracelsus, Paragranum, I, 8; 147-148: "nun merken in dem: sie sagen nach der alten philosophischen ler, aus mercurio und sulphure wachsen alle metall, item vom reinen erdrich wechst kein stein. Nun secht was lügen! Dan ursach, wer ist der, der do die materia der metallen allein sulphur und argentum vivum [mercury] sint zu sein, dieweil der metall und alle mineralischen dinge in drei dingen standen und nit in zweien?"

112 On this, see especially: Paracelsus, Opus Paramirum, I, 9; 39-23o; idem, De causis morborum invisibilium, I, 9; 251-350; see also: Schott, “'Invisible diseases."

113 Principe, The Secrets of Alchemy, 129. For new interpretations of spagyria, see: Newman, Atoms and Alchemy, 68-69.

114 Paracelsus, Paragranum, I, 8; 186: "darumb so in den arcanis der beschlußgrunt ligt, so muß hie der grunt alchimia sein, durch welche die arcana bereit und gemacht werden." 
makes gold, makes silver; here the purpose is to make arcana and to direct them against the diseases."115

Paracelsus did not invent alchemical medicine. It had been practiced by medieval alchemists such as Rupescissa, Roger Bacon, and Arnald of Villanova, to whom Paracelsus also referred, as well as by pseudo-Ramon Lull, and later it had attracted physicians in the fifteenth century. ${ }^{116}$ Roger Bacon, for example, had argued that the corruption of the body as a result of the Fall could be resolved through alchemical cures. ${ }^{117}$ Paracelsus reshaped and popularised this medieval application of alchemy to medicine, as a result of which it became increasingly popular amongst those who wished to distance themselves from traditional medicine. It is well known that Paracelsian spagyric medicine, mostly practiced and taught outside of universities, became particularly popular after 1570 for its chemically prepared cures. Early Paracelsians, especially those responsible for the dissemination of Paracelsus' medical works, remembered Paracelsus primarily as an iatrochemist, a chemical physician. They themselves, too, practiced, described, and prescribed (the study of) chymiatria. ${ }^{118}$

115 Ibid., 185: "nicht als sie sagen, alchimia mache gold, mache silber; hie ist das fürnemen mach arcana und richte dieselbigen gegen den krankheiten."

116 Lull himself probably never wrote alchemical texts, but such texts were published under his name. See further: Rupescissa, Liber de consideratione quintae essentiae omnium rerum deutsch; Benzenhöfer, Johannes' de Rupescissa liber de consideratione quintae essentiae omnium rerum deutsch; Pereira, The Alchemical Corpus Attributed to Raymond Lull; idem, "Medicina in the Alchemical Writings attributed to Raimond Lull"; Newman, "An overview of Roger Bacon's Alchemy"; Principe, The Secrets of Alchemy, 69-73; Devun, Prophecy, Alchemy and the End of Time; see also: Newman and Principe, "Alchemy vs. Chemistryç; Moreau, "Eléments, atomes, et physiologie," 117-120. On Paracelsus and medicine, see also the chapters included in: Dopsch, Goldammer, and Kramml (eds.), Paracelsus (1493-1541) 'Keines andern Knecht ...'.

117 DeVun, Prophecy, Alchemy and the End of Time, 83-84.

118 Examples are Adam von Bodenstein, Michael Toxites, Gerhard Dorn, Alexander Von Suchten, Oswald Croll, Samuel Eisenmenger, Joachim Tancke, Pseudo-Paracelsus. Cf. Eisenmenger (Siderocrates), De methodo iatromathematicae conjunctionis qua astrologiae fundamenta certissima indicantur; Dorn, Artificii chymistici physici (1569); Von Suchten, Tractatus secundus de antimonio vulgari (1604); Croll, Basilica Chymica; the letters by Bodenstein, Toxites, Dorn, Von Suchten, Penot and others reproduced in: Kühlmann and Telle, Corpus Paracelsisticum, vols. 1-3. Several alchemical Paracelsian tracts were also included in the six volumes of Theatrum chemicum, published by Lazarus Zetzner in the seventeenth century. The Theatrum chemicum included works by the Paracelsians Thomas Muffett, Dorn, and Penot. The spurious Manual on the Medical Philosophical Stone also describes the use of alchemy for the benefit of medicine: Manuale de lapide philosophico medicinali, I, 14; 421-432. See further: Hannaway, The Chemists and the Word; Kühlmann, 
So novel and antithetical were Paracelsus' ideas that he was soon dubbed the "Luther of medicine," especially and pejoratively by his opponents. ${ }^{119}$ Paracelsus emphatically rejected this epithet and argued: "With what mockery have you made me a caricature, calling me the Luther of physicians, with the explanation that I am a heresiarch [arch-heretic]? I am Theophrastus and I am more than he with whom you compare me. I am myself and I am the king of the phycisians. ${ }^{120}$ Despite his objections to this comparison, his medicine was indeed considered heretical to established medical scholars.

Like Paracelsus, the Rosicrucians were also pursuing a reform of medicine, and one which would involve the use of alchemy. It should be remembered that, in their view, "[p]hilosophy includes much of theology and medicine," and that the reform of one implied the reform of the others. ${ }^{21}$ Although the transformation of medicine was not explicitly addressed in the manifestos, passages about Rosencreutz and the brethren as physicians, like those examples provided above, indicated that the reform of medicine was one of their most abiding concerns. The brethren, after all, understood themselves first and foremost as physicians working outside of universities, ${ }^{122}$ and claimed that alchemy opens medicine and was "the highest medicine of the world."123 By linking alchemy to medicine, with the first being used for the benefit of the latter, the Rosicrucians advocated the use of alchemically prepared cures which their hero Paracelsus had popularised.

This use of spagyria represented a break with tradition. Traditional medicine was based on the works of Hippocrates of Kos (46o-37O BC), Galen of Pergamon (129-ca. 215) and Avicenna or Ibn Sina (980-1037). After the rediscovery of ancient texts in the eleventh century and their translations into Latin, Galen's medical and anatomical works became the standard authority within medicine during the Middle Ages. They were used alongside Avicenna's Canon of Medicine, a medical textbook also inspired by Galen's writings, which was

"Oswald Crollius und seine Signaturenlehre"; Kahn, "Alchimie et Paracelsisme”; Debus, The Chemical Philosophy; Kühlmann and Telle, "Einleitung," in: Corpus Paracelsisticum, vol. 1.

119 Kühlmann and Telle, Corpus Paracelsicum, vol. 2, 810.

120 Paracelsus, Paragranum, I, 8; 62-63: "mit was spot habt ir mich ausplasimirt, ich sei Lutherus medicorum, mit der auslegung ich sei haeresiarcha? Ich bin Theophrastus und mer als die, den ir mich vergleichent; ich bin derselbig und bin monarcha medicorum [...]." Cf. ibid., 43 .

121 Confessio, 45: "[philosophia] theologiae ac medicinae plurimum [...] habeat."

122 Although the Chemical Wedding is an overtly alchemical text, it does not express or relate to the general reformation of the other two manifestos, which is the central theme of this study.

123 Confessio, 58-59. Cf. above, n. 86. 
used at universities up to the eighteenth century (and was presumably the book burned by Paracelsus in Basel). Galenic medicine, influenced by the humoural theory of Hippocrates, treated diseases by correcting a surplus or shortfall of the humours (blood, phlegm, yellow bile, and black bile) that were thought to make up the human body. The humours, in turn, were related to the four temperaments and qualities. ${ }^{124}$ These four humours were also closely related to the four Empedoclean and Aristotelian elements (earth, water, air, and fire) and especially their qualities (each element had two of the qualities dry, wet, cold, and hot), by which also the Galenic humours were characterised. Traditional, Galenic medicine, based on the works of these authorities, remained dominant at universities in Europe in the sixteenth and early seventeenth centuries, but came under increasing pressure, especially by Paracelsus and his followers because it was unable to cure diseases such as leprosy, syphilis, and epilepsy. ${ }^{125}$ Paracelsus, rejecting Galenic medicine and the humoural theory, viewed human beings as individuals with individual diseases (rather than with humoural imbalances), which were to be cured by corresponding alchemically prepared cures. ${ }^{126}$

In the eyes of Paracelsus, not only was the Mercury-Sulphur dichotomy to be replaced by a trichotomy, but the theory of the four humours was a mere invention, because human beings consisted of the tria prima, instead. In his foremost challenge to traditional medicine, his Buch Paragranum (the book that goes against the grain), he provocatively wrote:

Although this philosophy of Aristotle, Albert, etc. has been written down, who will however believe the liars, who do not speak from philosophy, that is, from the light of nature, but from fantasy? Just as they invented in medicine the four humours, [namely] black bile, phlegm, etc., so also in philosophy they made up the lie about mercury and sulphur. ${ }^{127}$

124 On Galen and Galenic medicine, see for example: Hankinson (ed.), The Cambridge Companion to Galen; Tempkin, Galenism.

125 Cf. for example: Paracelsus, Von der Französischen Krankheit, I, 7; 67-181; Bodenstein, $C P$, vol. 1, nr. 23, 462 .

126 In Paracelsus' Astronomia Magna, one of the four pillars foundational to medicine is titled "alchemy"; see: Paracelsus, Astronomia Magna, I, 12; 3-444.

127 Paracelsus, Paragranum, I, 8; 148-149: "Wiewol dise philosophei von Aristoteles, Alberto, etc beschriben ist, wer wil aber glauben den lügern, die do nicht aus der philosophei reden, das ist aus dem liecht der natur, sonder aus der fantasei? gleich wie sie haben erdacht in der medicin 4 humores, choleram, phlegma, etc, also haben sie auch hie in der philosophei erdacht die lügen mit mercurio und sulphure." On this lie, see above, n. 111. "Choleram" originates from the Greek word "chole," meaning "bile." Cholera, then, was thought to 
The authors of the manifestos were obviously aware of the increasing rejection of Galenism by authors such as Paracelsus and his followers. While promoting the reform of medicine, the Rosicrucians included in their criticism of established learning specifically Galenic physicians, who feel that "one should stick to the old tunes and esteem the pope, Aristotle, Galen -indeed everything that has the appearance of a codex-more than the clear and manifest light; who [sc. Aristotle and Galen] if they were alive no doubt would happily correct their errors; but here man is too weak for such great works." ${ }^{\prime 28}$ Contemporary Galenic physicians were seen as perpetuating Galen's mistakes and were considered so vain that they cared more for their own reputations than for the truth. The Rosicrucian manifestos explicitly challenged and rejected the traditional medicine taught at universities, and endorsed a different type of medicine instead. No doubt this found its origin in the Paracelsian promotion of a new medicine at the expense of accepted authorities. Paracelsus and Christian Rosencreutz were understood to have been the heralds of this transformation.

According to the Fama, medicine was to be reformed, just like theology and law, and was also viewed as subordinate to philosophy. Unlike the other two disciplines, medicine was not sanctioned directly by the authority of the Church (unlike theology or canon law) or by the empire (unlike civil law), for which reason the Rosicrucian support of alchemically prepared cures and their criticism of Galenism was a direct offence neither to the Church nor to the empire. But the Rosicrucian reform of medicine and rejection of authorities was, of course, an offence to traditional university-taught and established physicians.

Because Galenism and Aristotelianism were so closely related, the rejection of the one implied the rejection of the other. In rejecting Galenism, both Paracelsus and Christian Rosencreutz were also dismissing the traditional Aristotelian natural philosophy as taught at universities, and seeking to replace it with their own philosophy. As has been mentioned in the previous chapter,

be bile coming out of the body. See also the second half of the passage: "[...] wie sich eins reimpt also auch das ander. sie zeigen vil auf den Albertum, Thomam, nit Albertus, Thomas, sonder sie, das ist ir, sollen darumb stehen. dan Albertus hat dise ler nit von $\mathrm{h}$. Geist gehabt, sonder nur aus vergebner speculation. also auch Thomas und ander, Hermes und Archelaus. darumb so mußtu dich underrichten lassen aus der natur, deren Albertus, Thomas, Aristoteles, Avicenna, Actuarius etc kein verstand anderst dan speculiren, das ist wenen, gehabt haben."

128 Fama, 93: "[Man] bleibe bey der alten Leyren [...] und muß Bapst, Aristoteles, Galenus, ja was nur einem Codice gleich siehet, wieder das helle offenbahre Liecht gelten, die ohn zweiffel, so sie lebten, mit grossen Frewden sich corrigirten: hie aber ist man so grossen Werken zu schwach [...]"; see also above, section 1.3. 
Rosencreutz formed his brotherhood in opposition to established teaching, and the authors of the manifestos were dismissive of Aristotle and his followers. The imperative to remove the pope as the Antichrist was mirrored by challenges to the authority of Galen and Aristotle, and the need for their legacies to be dismantled and replaced.

Aristotelian philosophy was the basis of the standard curriculum at universities. In the mid-twelfth century, Aristotle's work had been translated into Latin. The commentaries and scholarship that thereafter accrued to his work meant that his logic, metaphysics, moral philosophy, and natural philosophy subsequently came to form the foundation of university education. It is in the rejection of this received wisdom that we encounter the essence of the Rosicrucian call for a reform of philosophy. ${ }^{129}$ In the manifestos, the brethren instead promoted their own ideas, constituting a reform of natural philosophy.

In this regard they were, once more, following in the footsteps of Paracelsus and his disciples-at-a-distance, who in numerous places and in no uncertian terms had expressed their distaste for traditional philosophy in general and Aristotelianism in particular. Admonishing traditional university philosophers who followed medieval Arabic, Greek, and Latin authors, Paracelsus had suggested:

[...] you must follow me with your Avicenna, Galen, Al-Rāzī, etc., it is not me who must follow you. But you me, you from Paris, Montpellier, Salerno, Vienna, Cologne, Wittenberg, and all of you in the crowd, and none should be excluded, not remain even in the most remote little spa, because I am the monarch [...]. How would it be for you cuckolds, that Theophrastus will be the prince of the monarchy? And you the heaters [of spas]? What do you think of it, that you will have to enter my kingdom of philosophy and shit on your Pliny and Aristotle, and piss on your Albert, Thomas, Scotus etc., and [you] will say: "They could lie well and subtly, what great fools are we and our predecessors that they and we did not notice it.'.130

129 On Aristotelianism in the Renaissance and the early modern period, see: Schmitt, Aristotle and the Renaissance. See also: Lüthy, "What to Do with Seventeenth-Century Natural Philosophy." Cf. Fama, 98-99.

130 Paracelsus, Paragranum, I, 8; 137-138: "[...] ir müssen mir nach mit euerem Avicenna, Galeno, Rasi etc. und ich nit euch nach; ir mir nach, ir von Paris, von Montperlier, von Salern, von Wien, von Cöln, von Wittenberg und all ir in der summa, und keiner muß ausgenomen sein, im hindersten badwinkel nicht bleiben, des bin ich monarcha (und ich für die monarchei und gürt euch euer lenden). Wie wird es euch cornuten anstehn, das Theophrastus der monarchei wird der fürst sein? und ir calefactores? wie dünket euch, so ir werden in mein philosophei müssen und auf eueren Plinium, Aristotelem scheißen, auf 
This fierce rejection of established philosophical and medical thought and the promotion of Paracelsus' own ideas was copied by early Paracelsians. Bodenstein, for example, claimed that true knowledge had been lost upon the entry to the philosophical stage of Aristotle, whom he described as having been "the wonder of nature and a demonic man." University scholars erred because they still followed his example: "The theologians who followed Aristotle, fell in many disgraceful ways into errors and brought excessively loathsome heresies into the churches, because they mingled the sacred with the profane and the heaven with the earth."131 Just like the authors of the manifestos, Bodenstein referred to the practice in universities with the term "heresy," because scholars persisted in errors that were offensive to God. ${ }^{132}$ This label applied especially to the theologians, who involved the pagan Philosopher in theological matters.

Bodenstein was the son of the religious reformer Andreas Karlstadt von Bodenstein (1486-1541), who originally collaborated with Luther and was aware of, and influenced by, Luther's early uncompromising criticism of Aristotle and scholastic philosophy in general. ${ }^{133}$ Bodenstein's dismissal of the use of Aristotle in theology perhaps found its origin in his father's criticism of this practice in the early days of the Reformation. During the Wittenberg movement, when Luther was exiled at Wartburg Castle, Karlstadt distanced himself from the famous reformer and developed views that were soon deemed too radical by Luther himself. During this time, Karlstadt preached vehemently against the mixture of pagan Aristotelianism and theology that he felt ought to be concerned with divine matters. ${ }^{134}$ It was mainly Karlstadt's radicalism that prompted Luther to return from his exile to steer matters into a different direction. Upon Luther's return, Karlstadt was forced to leave Wittenberg and to lead a life quite like that of Paracelsus, as a lone drifter. ${ }^{135}$ Bodenstein may well have been inspired both by his father's stance, which drew such fierce early criticism, and by Paracelsus' outbursts against the Philosopher. The Karlstadt-

eueren Albertum, Thomam, Scotum etc. seichen und [ir?] werden sprechen: die konten wol und subtil liegen, wie große narren sind wir und unser vordern gewesen das sies und wir nie gemerkt haben."

131 Bodenstein, $C P$, vol. 1, nr. 6, 116: "[...] Hinc Graeci Platonem appellabant diuinum, et Aristotelem naturae miraculum et daemonium [...]"; "Theologi autem, qui Aristotelem secuti sunt, turpissimè in multis aberrarunt, ac haereses nimis foedas in ecclesias inuexerunt: quia sacra prophanis et coelum terrae miscuerunt."

132 For the Rosicrucians and the term "heresy," see above, section 1.3.

133 Roper, Martin Luther, 220-221.

134 Sider, Andreas Bodenstein von Karlstadt, 55.

135 Dixon, "The Radicals," 191-193. 
connection, in any case, provides the religiously abstruse backdrop to some of the Rosicrucians' precursors.

The reform of knowledge propagated by the Rosicrucians involved the formulation of a better alternative to Galenic, Aristotelian, and scholastic practices, for which they turned to Paracelsus. Importantly, however, and for reasons that remain obscure, the Rosicrucians never referred specifically to Paracelsus concerning (alchemical) medicine or the rejection of Aristotelian thought. Like Paracelsus and the early Paracelsians, they described themselves as physicians, supported spagyria, and scorned Galenic physicians, but they were never explicit in their adoption of Paracelsian medicine. This is surprising, given that it was his medicine that formed the primary basis for Paracelsus' popularity around 1600 . While Paracelsians were not the only ones to use chemically prepared cures as a remedy for diseases, and while some physicians came to use these cures in combination with Galenic medicine, alchemical medicine remained first and foremost related to the medicine of Paracelsus, and Paracelsus was still primarily known more for his iatrochemistry than for his other, e.g. religious, contributions. ${ }^{136}$ Although the Rosicrucian criticism of Galenism and scholastic Aristotelianism was not explicitly derived from Paracelsus or Paracelsians, it must have been motivated by the growing rejection of Galen and Aristotle by Paracelsians.

\subsection{Philosophical Inspirations}

The Rosicrucians implicitly sided with Paracelsus and early Paracelsians in their rejection of scholastic thought and acceptance of spagyrical medicine, but, more importantly still, they explicitly accepted and promoted the new philosophy of Paracelsus and his followers as their own. By doing so, they positioned Paracelsus as a precursor of the Rosicrucians' own philosophy and, indirectly, of their general reformation. While his name occurs several times in the Fama, there are no references to him in the Confessio and the Chemical

${ }_{13}$ Severinus and Sennert are well known for having combined both strands of medicine, although Sennert accepted fewer Paracelsian ideas than Severinus; see: Severinus, Idea Medicinae; Shackelford, "The Early Reception of Paracelsian Theory"; idem, "To Be or Not to Be a Paracelsian"; idem, A Philosophical Path for Paracelsian Medicine; Hirai, "Living Atoms, Hylomorphism and Spontaneous Generation in Daniel Sennert"; Moreau, "Eléments, atomes, et physiologie". Other examples include Johannes Hartmann and Joseph DuChesne (Quarcetanus); see: Moran, The Alchemical World of the German Court; Kahn, "Alchimie et Paracelsisme." 
Wedding. The repeated suggestions that Paracelsus' name appears in a cryptogram inscribed on a basin in the Chemical Wedding cannot be verified. Kienast's reading of the cryptogram ignores any possible astronomical or alchemical symbolism, and one can only make out a reference to "Paracelsus Hochheimensis Medicinae Doctor" when one reads into four strange characters four letters from three different alphabets (Greek, German, and Latin). The characters said to refer to Paracelsus could just as easily be interpreted to refer to anything else. Moreover, a reference to Paracelsus would make little sense: it would be a unique instance in the Wedding, and there is no obvious connection between Paracelsus and what, according to Kienast, are occult elements in the cryptogram. Contrary to the Fama and the Confessio, the Wedding does not reveal any Paracelsian inspiration, even if alchemy constitutes part of the subject matter. A reference to Paracelsus would be at odds with the rest of the text and therefore lacks plausibility. ${ }^{137}$

The centrality of Paracelsus in the Fama is evident from the episode recounting the rediscovery of Christian Rosencreutz's vault, a central episode of this manifesto. Hidden in the vault, deep below the house of the Rosicrucian brotherhood called Holy Spirit, and next to the body of the founder of the fraternity, a Paracelsian work was discovered. As the third generation of brethren of the fraternity opened the vault, they discovered the following:

Each side [of the vault] had a door to a chest, in which lay various things, especially all our books, which we already possessed, together with the Vocabulary of Theophrastus Paracelsus von Hohenheim and those books of which we faithfully report daily: Herein we also found his Itinerary and Vita, from which most of this [work] is taken. ${ }^{138}$

137 For the cryptogram, see: Chemical Wedding, 118. Scholars suggesting that Paracelsus' name could be read here include: Kienast, Johann Valentin Andreae und die Vier echten Rosenkreutzer-Schriften, 9o, followed by: Montgomery, Cross and Crucible, vol. 1, 198; Edighoffer, Rose-Croix et société idéale, 237 idem, "L'énigme Paracelsienne," 238; Gilly, Cimelia Rhodostaurotica, 7 ; idem, "Vom ägyptischen Hermes," 72.

138 Fama, 116-117: "Eine jede der seyten [des Gewölb] hatte eine Thür zu einem Kasten, darinnen unterschiedliche sachen lagen, besonders alle unsere Bücher, so wihr sonsten auch hatten, sampt deme Vocabulario Theoph. P. ab: Ho. und denen so wihr täglich ohne falsch mittheilen: Hierinn funden wihr auch sein Itinerarium und Vitam, darauß dieses meisten theils genommen [...]." "Theoph P. Ab: Ho" is short for "Theophrastus Paracelsus ab Hohenheim." Tilton claims that in the vault books were found containing the "prisca sapientia," but this is not clear from the description in the Fama: Tilton, "The Rosicrucian Manifestos and Early Rosicrucianism," 128. 
The Itinerary and Vita are presumably Rosencreutz's, not Paracelsus', because only Rosencreutz's itinerary and life are described in the Fama. But next to the society's important founding works lay Paracelsus' Vocabulary. Both the explicit reference to Paracelsus as well as the sacred place where his book was found are indicative of the importance the authors attached to this philosophical, medical, and religious reformer. But to what does the Vocabulary refer? Is this a reference to a work unknown to us today? It is well known that the cryptic nature of Paracelsus' works meant that they were often difficult for readers to interpret. Might the Vocabulary therefore have been a work that enabled the Rosicrucian brethren to unlock the full significance of Paracelsus' writings by providing clear and authoritative definitions for his terminology? It certainly seems that the fraternity was claiming unique authority to expound Paracelsus' writings based on a treatise that could unlock his code. The implication of this reference to the Vocabulary is that the Rosicrucians have fully incorporated Paracelsian concepts into their worldview.

From the point of view of a literal interpretation, it is impossible that works by Paracelsus or Paracelsians could have been found in the vault. The legendary Rosencreutz is said to have died in 1484, ten years before Paracelsus' birth in $1493 / 4$, and the vault allegedly was not opened before $1604 .{ }^{139}$ Perhaps the authors of the manifestos were unaware of Paracelsus' dates of birth and death. But on the more likely supposition that they were aware of Paracelsus' biography, they deliberately placed him outside of time, thereby conferring upon him a mythological status. He then inhabits a mythological world, similar to the one attributed to both Elias Artista and Christian Rosencreutz, from where he inspires the Rosicrucians' philosophy and their narrative context.

Still, the reference to Paracelsus is not entirely unforeshadowed, because in the years before the manifestos were drafted the publication of hundreds of his works was answered with a similarly prodigious flow of books by other authors who popularised his philosophy. The authors of the manifestos must have been aware of this flood of publications and owed an intellectual debt to the medical reformer. Paracelsus, using a specific and unconventional terminology, had at times provided explanations of individual terms, which could have been known to the Rosicrucians. ${ }^{140}$ It could also be that the Vocabulary refers to one of the thematic lexica published at the end of the sixteenth century. One of these was the Dictionary of Theophrastus Paracelsus (1584) by Dorn, in which Paracelsian terms are discussed and explained. It might also have been

139 The vault was described as having been hidden for 120 years, see: Fama, 113, 119 .

140 See, for example: Paracelsus, Vom Bad Pfäffers, Huser, VII, $242 \mathrm{ff.}$ 
a reference to one of the Onomastica (thematic lexica) published in the 1570 s and 158 os by authors such as Toxites, Bodenstein, and Thurneysser, who themselves contributed greatly to the diffusion and popularisation of Paracelsus' writings. ${ }^{141}$ The opaque writing style of Paracelsus, alongside the occasionally chaotic structure of his texts and his habit of inventing new words, had proven challenging to the early modern reader. ${ }^{142}$ Works like those by Dorn and Thurneysser organised and codified Paracelsus' texts. Since such works were key resources for understanding the obscure language of Paracelsus, it is plausible that the brethren referred to one of them, and were thereby claiming to have the key to unlock the meaning of Paracelsus' new philosophy.

What, then, was this new philosophy? What was Paracelsus' explicit contribution to the Rosicrucian cause and their call for a general reformation? We have seen that the authors of the manifestos referred to the efforts of unnamed heroes towards the reformation of the world on the eve of the new period. The only one such hero mentioned by name was Paracelsus:

We must certainly acknowledge that the world even in those days was already pregnant with great commotion and was labouring to give birth, and that she already brought forth tireless, worthy heroes, who forcefully broke through the darkness and barbarism, so that we weaker ones could press on after them. They were the tip in the Fiery Trigon, whose flames now shine even more brightly and will certainly kindle in the world the final fire. One of these men, in his calling, was Theophrastus. ${ }^{143}$

That the world was labouring to give birth depicts metaphorically the birth of the new age. As preparation for this birth, Theophrastus Paracelsus had

141 Toxites, Onomasticon I \& II (1574); Thurneysser, Onomasticon (1574-1583); Bodenstein, Onomasticon Theophrasti Paracelsi (1575); Dorn, Dictionarium Theophrasti Paracelsi continens obscuriorum vocabularum, quibus in suis scriptis passim utitur definitiones (1584); see also: Edighoffer, Les Rose-Croix et la crise, 164.

142 The claims by Paracelsus' assistant, Johannes Oporinus, that Paracelsus would dictate his writings to students, sometimes even while he was still drunk from the night before, might lend further explanation to the impenetrability of his works; see: Sudhoff, Paracelsus. Ein deutsches Lebensbild aus den Tagen der Renaissance, 46-49.

143 Fama, 100-101: "Gewißlichen wihr müssen bekennen, daß die Welt schon damahls mit so grosser Commotion schwanger gangen und in der Geburt gearbeitet, auch sie so unverdrossene rühmliche Helden herfür gebracht, die mit aller Gewalt durch die Finsternuß und Barbarien hindurchgebrochen und uns schwachern nur nachzudrucken gelassen und freylich der Spitze im Trigono igneo gewesen, dessen Flammen numehr je heller leuchtet und gewißlichen der Welt den letzten Brand antzünden wird. Ein solcher ist auch in seiner Vocatio gewesen, Theophrastus [...]." 
appeared alongside some other worthy heroes whom the Rosicrucians would follow and whose contributions were to be used for the future reformation. Paracelsus worked his way through darkness and barbarism, which presumably signified scholastic thought, and reformed some of the arts. As part of the imminent final fire-a reference to the idea that the world will be consumed in a final conflagration before being made new again - the Fiery Trigon signals in the skies the advent of the new period. Although less likely, the blazing fire might also have carried an alchemical connotation. According to Paracelsus' Paragranum, calcination was one of the first steps in transmutational alchemy, which was accepted as a parergon in the manifestos. Calcination was conducted under the influence of fire. ${ }^{144}$ In this sense, it might be regarded as the first step towards the renewal of the world by fire, in which case transmutational alchemy would play a significant role in the renovation of the world.

Immediately after the passage just quoted, it becomes clear in what sense Paracelsus was taken to be a worthy hero announcing and contributing to the Rosicrucians' reformation. The Fama expands on Paracelsus' specific merits as follows:

[...] although he [Paracelsus] never entered our fraternity, he had nonetheless diligently read the Book M., which had ignited his sharp mind. But this man was so hindered in his best course by the preponderance of the learned and the know-it-alls, that he could never peacefully discuss his considerations concerning nature with others. Therefore, in his writings he rather mocked these know-it-alls than revealing himself fully. ${ }^{145}$

Throughout his life, Paracelsus was unable to engage in peaceful dialogue with others, and his writings are verily interspersed with sarcastic comments on

144 Paracelsus, Paragranum, I, 8; 187: “[...] also hier auch im feur die zerbrechung geschihet. Und da fermentiren sich die arcanen und geben von inen die corpora und gehent in ir aufsteigen zu iren exaltationibus, deren zeit ist calcineren, sublimiren, reverberiren, solvireren, etc." Through calcination metals or minerals turn to dust or powder under the influence of fire.

145 Fama, 101: "Theophrastus, so gleichwohl in unsere Fraternitet nicht getretten, aber doch den Librum M. fleissig gelesen und sein scharffes ingenium dardurch angezündet. Aber diesen Mann hat der Gelehrten und Naßweysen Ubertrang auch in dem besten Lauff gehindert, daß er sein Bedenken von der Natur nimmer friedlichen mit andern conferiren, und deßwegen in seinen Schrifften mehr der Fürwitzigen gespottet, als daß er sich gantz sehen lassen [...]." The anti-Paracelsian and anti-Rosicrucian Libavius, who identified himself with the learned community, would later take offence at this passage; see: Libavius, D.o.M.A. Wohlmeinendes Bedencken von der Fama und Confession, 79-80. On Libavius, see below, section 5.1. 
traditional philosophers and physicians. Medically, Paracelsus had become increasingly notorious, especially after the expulsion from Basel. Religiously, by the end of his life, he claimed " $t$ ] hat is the foremost reason that has hindered me to write: that I have not been taken for an entitled Christian; that has troubled me much."146 Paracelsus had never matriculated in theology, and was therefore not taken seriously by university-taught theologians who may have questioned his Christian fidelity, but who in any case problematised the fact that Paracelsus styled himself as a doctor in Scripture. ${ }^{147}$

Here we find another similarity between the heterodox physician and Christian Rosencreutz: according to the manifestos, both men had studied the Liber M. Paracelsus was said to have read this book, while Rosencreutz had translated it into Latin and brought it with him from Damcar. ${ }^{148}$ With this analogy, the Rosicrucians once more co-opted Paracelsus as an ally of Rosencreutz and the Rosicrucian cause.

The Liber M. in the manifestos was perhaps the Liber mundi, the "Book of the World" or the Book of Nature, referred to also by Paracelsus. But the Rosicrucians' Liber M. must refer to something else, or more, than simply to nature as it appears before our eyes, otherwise Rosencreutz did not need to translate it from Arabic and bring it with him to the German-speaking regions. The Rosicrucians claimed to have in their possession secret knowledge, about which Rosencreutz was taught in Fez, and it may very well be that the Liber M. was the key that granted them (and others) knowledge of the secrets hidden in nature, making this book a manual that could help to decrypt nature's mysteries. Understood in this sense, most people had forgotten or lost the ability to probe beyond nature's surface and properly read the book of nature-with the exception of a few enlightened men in Fez who had preserved this secret knowledge - and the Liber M. served as a repository of this information.

The idea that the Liber M. signifies a unique code to decipher nature's secrets is testified by another reference to the Liber M. in the Fama. This reference

146 Paracelsus, De secretis secretorum theologiae, II, 3; 169: “[...] und über alles das, das ich erzelt hab, das dann der wenigste teil ist. der mehrer ist groß, daß ich ihn nit beschreiben mag. das ist die größeste ursach die mich gehindert hat zu schreiben, daß ich nit für ein volmächtigen christen bin geachtet wordnen; das mich hart betrüebt hat [...]. mir ist entgegen gestanden ein anderer hauf und reich, der da gesagt: du als ein lai, als ein paur, als ein gemein mann solt von den dingen nit reden, was die heilig geschrift antrifft, sonder uns zuhören, was wir dir sagen, dabei bleiben, und kein anderen sollstu hören oder lesen dann allein uns."

147 Kühlmann and Telle, Corpus Paracelsisticum, vol. 1, 556.

148 Fama, 95: "In Damcar lehrnet er die Arabische Spraach besser, wie er dann gleich in folgendem Jahr das Buch und Librum M. in gut Latein gebracht, unnd mit sich genommen." 
implies that by means of secretly reading the "Book M.," the Rosicrucians could observe the entire world "before their eyes." ${ }^{149}$ In the Salzburg manuscript version of the Fama, this passage refers to the "Book mysteriorum" rather than to "Book M.," 150 which further gives the impression that the book contained the key to all the mysteries of the world. Likewise, the Confessio stated that "the Book of Nature is opened wide before the eyes of all, even though few can either read or understand it."151 The study of nature required a unique means to decipher all its secrets, and the Rosicrucians seemed to believe that they now had such a key in their possession. Paracelsus was thus seen as one of the few humans capable of studying and understanding the secrets buried in the Book of Nature.

A third and final reference to this book - and in the Salzburg version to the "Book mysterium"152 — explains that Rosencreutz began writing the first part of the Book M. together with the first brethren of the Rose Cross. As the task of writing the Book M. became too heavy for them, others were admitted into the brotherhood to help out with their daily chores. ${ }^{153}$ That Rosencreutz translated the book into Latin, and that he wrote it together with the other brethren, may suggest - despite the incongruity of writing a book that he had translated earlier and that thus was already in the brethren's possession - that it was to serve as a means to make hidden knowledge public. Latin was still the lingua franca of the scholarly community, and scholars communicated their ideas to the international intellectual community predominantly through Latin works. It may be that the Rosicrucians had similar objectives in mind for this book.

According to tradition, the Book of the World was interpreted as the Book of Nature, creation, complementing the Book of Scripture. Traditionally, both

149 Ibid., 109: “[...] was wihr auch auß dem Buch M. heimlichs erfahren/ (wiewohl wihr der ganzen Welt imaginem und contrafactur können für augen haben), ist uns doch weder unser Unglück unnd Serbstündlein bewust [...]."

$15^{\circ}$ Fama Fraternitatis, Universitätsbibliothek Salzburg, Ms M I 463, 6v .

151 Confessio, 55: "De sua quidem voluntate jam praemisit nuncios Deus, Stellas in Serpentario atque Cygno exortas, quae magna profecto magni Consilii signacula illud docere possunt, quam junctis iis, quae humanum ingenium adinvenit, suae occultae scripturae inservire faciat, ut Liber Naturae in omnium quidem oculis expansus adapertusque sit; pauci tamen vel legere omnino, vel intelligere possint."

$15^{2}$ Fama Fraternitatis, Universitätsbibliothek Salzburg, MS M I 463, $4^{\mathrm{r}}$. Note that this time the text reads "mysterium" rather than "mysteriorum."

153 Fama, 104: The first brothers "machten auch den ersten Theil des Buchs M. weil ihnen aber die Arbeit zu groß worden und der Kranken unglaublichen zulauff sie sehr hinderten, auch allbereit sein newes Gebäw Sancti Spiritus genennet, vollendet war, beschlossen sie noch andere mehr in ihr Gesell und Brüderschafft zu ziehen." See also the reference to the Book M. on ibid., p. 109. 
books, scriptural and natural, were thought to be the means through which God expressed himself. 154 The Bible was the revealed Word of God, but God had revealed Himself also through His creation, in order for His existence to be knowable to all people, even to those who had not received His Word. ${ }^{155}$ The French theologian Alanus ab Insulis (Alan of Lille, 1120-1202) wrote a famous poem that was thought to refer to the Book of Nature, and which begins with the following triplet:

$\begin{array}{ll}\text { Omnis mundi creatura, } & \text { Each creature of the world, } \\ \text { Quasi liber, et pictura } & \text { is like a book, and a picture } \\ \text { Nobis est, et speculum. } & \text { for us, and like a mirror. }{ }^{156}\end{array}$

The theory of the two books, Nature and Scripture, was well known in the Middle Ages, but became popular-and open to a variety of interpretationsespecially in the sixteenth and seventeenth centuries. It influenced the works of such natural philosophers and scientists as Oswald Croll (1563-16o9), Francis Bacon (1561-1626), Galileo Galilei (1564-1642), Robert Boyle (1627-1691), and others. This analogy between Scripture and nature occasionally mixed with traditions like the philosophia perennis, and some concluded that while after the Fall humans were cut off from immediate divine inspiration, through Scripture and nature they were still able to acquire such original knowledge. ${ }^{157}$ Both the theory of the two books, as well as the philosophia perennis, were central to

154 On the book of nature, see: Blair, Theatre of Nature; Trepp, "Im 'Buch der Natur' lesen"; Howell, God's Two Books; Van Berkel and Vanderjagt (eds.), The Book of Nature in Antiquity and the Middle Ages; idem, The Book of Nature in Early Modern and Modern History; Harrison, "The 'Book of Nature' and Early Modern Science"; Palmerino, "The Mathematical Characters of Galileo's Book of Nature"; Van der Meer and Mandelbrote (eds.), Nature and Scripture in the Abrahamic Religions up to 1700; Bono, "The Two Books and Adamic Knowledge"; Jorink and Mason, Reading the Book of Nature in the Dutch Golden Age, 15751715 , especially chapter 2 . Such ideas had their origin in the Bible, consider for example: Romans 1:20; Psalm 19.

155 Cf. for example: Augustine, Enarratio in Psalmum XLV, 7, mentioned in: Jorink and Mason, Reading the Book of Nature, 40-41.

${ }_{15} 6$ Alanus ab Insulis, De Incarnatione Christi, in Patrologia cursus completus, series Latina, 210, p. 579. On Alanus, see, for example: Evans, Alan of Lille: The Frontiers of Theology in the Later Twelfth Century.

157 Bono, "The Two Books and Adamic Knowledge," 301-307. These authors could not have been sources for the Rosicrucians. Croll's Basilica Chymica (16o9), in which he adopted the two-books theory corresponding to two lights, became very popular after Croll's death in 1609 . 
the Rosicrucian general reformation; they were each fundamental to the new citadel of truth which for the Rosicrucians was to replace traditional thought.

Paracelsus gave his own description of the Book of Nature. He had suggested that one should study nature just as his predecessors had studied books. Studying paper books, he argued, would help us neither to acquire new knowledge nor to understand local or new diseases. In analogy with Alanus, Paracelsus argued that one should instead read nature like a book:

Then this is what I want to attest concerning nature: whoever wants to investigate it, should study its books with his feet. Scripture is studied through its characters, but nature from country to country: A country is like a page. Thus is the codex of nature, thus must its leaves be turned. ${ }^{158}$

Paracelsus, distancing himself from the bookish study of the scholastics, turned his attention to the external world to acquire empirical knowledge-while never neglecting the importance of Scripture and divine inspiration. Bodenstein later testified that Paracelsus "used new principles, which he proved by means of the Holy Scripture and experience itself [...]."159 Both this passage and Paracelsus' numerous studies and interpretations of biblical texts indicate his concern for the natural and scriptural books.

Corresponding to the two books, Paracelsus postulated two lights, the light of nature and the light of the spirit. ${ }^{160}$ The light of nature, he argued, comes from God the Father, to inspire human beings to study all worldly things. The light of the spirit (or the light of grace) comes from God the Son, to illuminate matters of faith, especially regarding the life of Christ and the life in Christ. ${ }^{161}$ With the help of the light of nature, one could cure diseases, study nature, and create artefacts:

$15^{8}$ Paracelsus, Sieben defensiones, I, 11; 145-146: "[D]an das wil ich bezeugen mit der natur: der sie durchforschen wil, der muß mit den füßen ire bücher treten. Die geschrift wird erforschet durch ire buchstaben, die natur aber durch lant zu lant: als oft ein lant als oft ein blat. also ist codex naturae, also muß man ire bletter umbkeren."

159 Bodenstein, $C P$, vol. 1, nr. 6, 117: Paracelsus "nouis principijs est usus, quae sacris literis ipsaque experientia probat [...]."

16o Paracelsus, Liber de sancta trinitate, II, 3; 259-26o: "Zwei liecht seindt, menschlich und geistlich und komben beide von gott, nemblich das liecht der weisheit und das liecht des menschlichen lebens und das liecht des glaubens und des geistlichen lebens [...] eine zu menschlicher vernunft, die ander dienet zum glauben. und eine gehört auf erden, undter uns zum leben in der liebe des nechsten, die ander hört in den glauben, zum ewigen reich $[\ldots] . "$

161 Ibid., 26off. On the importance of an ethical, Christian life in Paracelsus, see: Biegger, De invocatione, 50; Daniel, "Paracelsus' Astronomia Magna"; idem, "Paracelsus on Baptism"; Gantenbein, Paracelsus, 6. 
The light that is given to man by God the Father is such a light that through this light humans learn all worldly things, which belong to the world, [and] to the body. When something is equal to the light of nature, it is known properly. Because the light of nature, the knowledge of humans about all worldly things, is nothing but the Holy Spirit of God the Father. ${ }^{162}$

It is the light of nature, originating from God, which Paracelsus believed would enable humans to study the Book of Nature. The Rosicrucian characterisation of Paracelsus as student of the Liber M. presumably found its origin in such passages.

The theory of the two books continued to be influential among later followers of Paracelsus. A case in point was Toxites, who had already referred to the light of nature, and claimed:

God wants the human being [...] to study the secrets in all of God's gifts, in the heavenly and earthly philosophy and astronomy, so that he focuses on the natural and the eternal in the work, so that he may not only know God correctly through it, and serve his fellows, but so that he may reveal himself with it, so that others may perceive his work and acclaim and praise God.163

Like the authors of the manifestos, Toxites suggested that knowledge of the natural and divine realms was possible. ${ }^{164}$

In two ways, this analogy between Scripture and nature stands in contrast to the Lutheran notion of sola scriptura. Firstly, Luther put the emphasis on Scripture alone and never complemented this one book with another; his

162 Paracelsus, Liber de sancta trinitate, II, $3 ; 262-263$ : "[S]o ist das liecht so vom vatter dem menschen geben wird, ein solches liecht, daß durch dasselbig liecht die menschen alle weltliche ding lernen, die in die welt gehören, zu dem leib. ist etwas gleich dem liecht der natur, in dem so es recht erkent wird. wann lumen naturae, das wissen des menschen in allen weltlichen dingen, ist nichts als der heilig geist von gott dem vatter [...]."

163 Toxites, preface to Astronomia Magna, Avi-Avii: "Derhalben will Gott daß der Mensch nicht feire oder müssig gehe/ sonder daß er in teglicher ubung bleibe/ zu erforschen die heimligkeiten in allen gaben Gottes/ in der Himlischen und irdischen Philosophey und Astronomey/ damit er das natürlich/ und das ewig in das werck richte/ auff das er nicht allein Gott dadurch recht lerne erkennen/ und dem Nehesten damit diene/ sonder daß er sich damit offenbare/ damit andere seine werck sehen/ und Gott darumb loben und preisen."

164 Fama, 91-92, see above, section 1.3. 
Reformation was solely grounded in scriptura and traditio. Secondly, Luther turned to Scripture in order to salvage faith and not as a means to knowledge. The Rosicrucian study of both books, instead, provided insights into natural and divine things, and both the Rosicrucian and Paracelsian views are in keeping with the renewed stress on human agency as opposed to divine revelation alone.

In the manifestos, the external world that was to be studied also corresponded to the inner world of man: both worlds, the macrocosm and the microcosm, were understood to be in harmony. The microcosm and macrocosm were each a mirror to the other; everything in the macrocosm had its equivalent in the microcosm. The Fama described this harmony as follows:

Just as every seed contains a whole good tree or fruit, likewise the entire great world is contained in a small human being, with his religion, politics, health, bodily parts, nature, speech, words and works, all in the same tone and melody with God, heaven and earth. ${ }^{165}$

The potential for human beings to find themselves in harmony with God, the firmament, and the external natural world, implies that as microcosms they contain something within them corresponding to God, heaven, and earth. This is an important element of the Rosicrucian understanding of human nature. It is also again contrary to Luther's view: if humans were "in the same tone" as God, they were not corrupted by sin, while also religion was understood to be an internal experience and not solely an outward expression of the lived service of God.

Already on the opening page of the Fama, humans are introduced as microcosms of the universe. We recall from above that God was said to have revealed secrets and previously hidden creatures in the macrocosm, and highly illuminated minds were said to have come to renew the arts. Thanks to these important developments, the Fama stated, "the human being may understand his nobility and glory, in what way he is the microcosm, and how far his art extends into nature."166 Because of the harmony between the microcosm and the macrocosm, revelations in the universe and the renewal of the arts and philosophy on

165 Fama, 97-98: "[G]leich wie in jedem Kernen ist ein gutter gantzer Baum oder Frucht, also die gantze grosse Welt in einem kleinen Menschen were, dessen Religion, Policey, Gesundheit, Glieder, Natur, Spraache, Worte und Wercke, aller in gleichem tono und Melodey mit Gott, Himmel und Erden ginge."

166 Ibid., 92: "[...] damit doch endlich der Mensch seinen Adel und Herrlichkeit verstünde, welcher gestalt er Mircocosmus, und wie weit sich sein Kunst in der Natur erstrecket." 


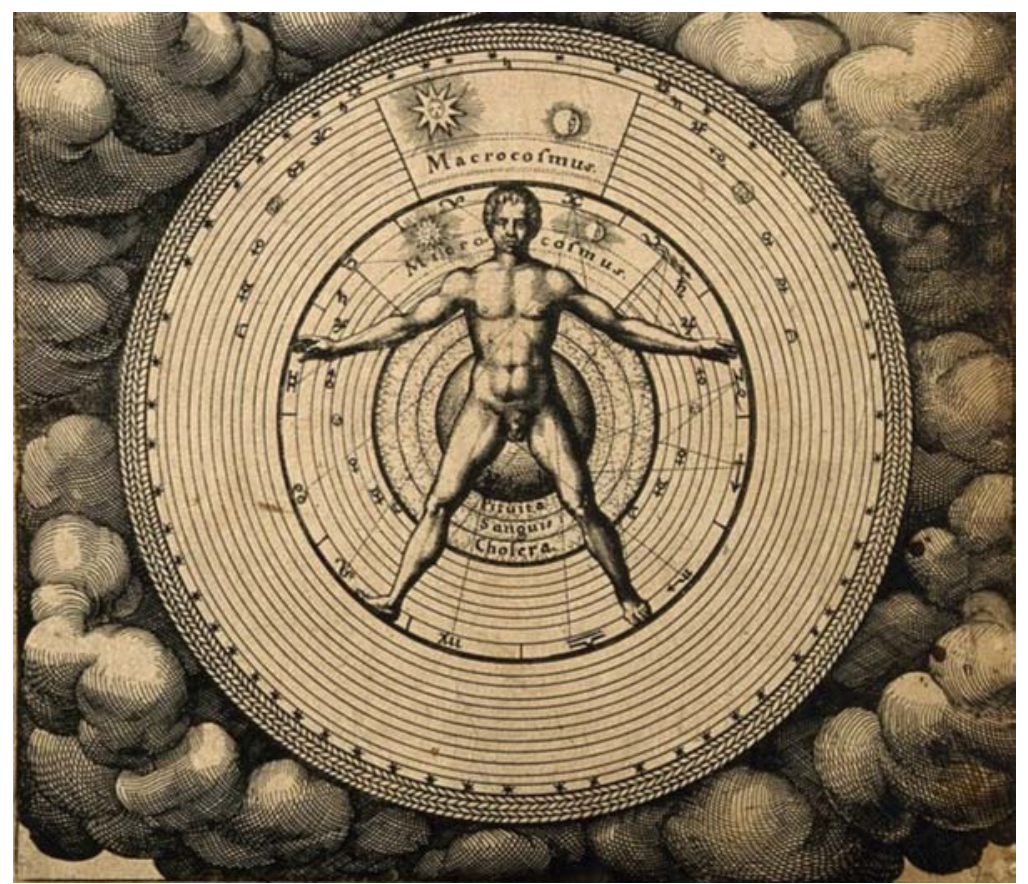

FIGURE 5 Fludd, Utriusque cosmi historia, line engraving by Theodor de Bry, Wellcome Collection

the eve of the new age implied a re-evaluation and reinterpretation of humans themselves. Within them, that which was in harmony with the macrocosm, was divine; that which was not, could be considered devilish. ${ }^{167}$

In the Confessio, the authors explained: "Philosophy [...] examines heaven and earth through a more careful anatomy, or, to put it briefly, we say it expresses sufficiently the one man, the microcosm."168 For the Rosicrucians, philosophy could be used to study the nature of the universe, the macrocosm, as well as the nature of human beings, the microcosm. It encompassed astronomy and natural philosophy for the study of the heavenly and natural worlds, and religion for the study of the divine. Astronomically, humans were seen as the centre of the cycles of the sun and the moon. ${ }^{169}$ Religiously, having a

\footnotetext{
167 Ibid., 97-98.

168 Confessio, 45: "[...] philosophia [...] caelum atque terram exquisitiori Anatomia scrutetur, aut ut summatim dicamus, Unum hominem Microcosmum satis exprimat." This is one of the sentences also found in the Theca gladii spiritus (1616), 31, nr. 177, written by Andreae but published under Hess' name; see the Appendix.
}

169 Confessio, 62-63. 
divine counterpart within, they may once again understand their (original) glory. They were both actors of the general reformation as well as objects of study in all their earthly and heavenly aspects. The renovation of philosophy thereby cleared the path for the renovation of the world. ${ }^{170}$

These statements about humans as microcosms echo earlier ideas. The famous phrase on the Emerald Tablet (Tabula Smaragdina), to which Bodenstein referred, was attributed to the legendary Hermes Trismegistus and reads as follows: "That which is below is like that which is above, and that which is above is like that which is below."171 During the Middle Ages and the early modern period, this formula had a considerable influence. Ficino invoked the analogy of microcosm and macrocosm in his Three Books on Life (De vita libri tres), which was written in the 148 os. $^{172}$ But it was in fact Paracelsus to whom the authors of the Fama referred when speaking of this harmony:

This harmony is profoundly present in his [Paracelsus'] works, which he would have shared with the learned without doubt, if he had found them to be worthier of higher art rather than of subtle mocking. So he wasted his time living free and carefree, leaving the world to its own foolish pleasures. ${ }^{173}$

While Paracelsus had discussed the microcosm-macrocosm analogy in his works, the Rosicrucians were nevertheless critical of him for squandering his life away. ${ }^{174}$ As for Paracelsus himself, he knew Ficino's work, as is clear from a reference to the latter as the "best of the Italian physicians" in a letter to Christoph Clauser. ${ }^{175}$ Later Paracelsians were also familiar with Ficino and with the

170 Confessio, 45. Cf. above, section 1.3.

171 On Hermes, see: Kahn, Hermès Trismégiste. The notion of man as microcosm is not specifically a Paracelsian or Hermetic idea, but it was a widespread concept also in other traditions in the Middle Ages and the early modern period. See, also for further literature: Weeks, Paracelsus. Essential Theoretical Writings, $113 \mathrm{n} 1$ and n2.

172 On this analogy in the Renaissance, see also: Yates, Giordano Bruno; Gentile and Gilly, Marsilio Ficino; Daniel, "Paracelsus' Astronomia Magna," 134-228; Hanegraaff, Dictionary of Gnosis, 1127-1128; Robichaud, "Ficino on Force, Magic and Prayers."

173 Fama, 101-102: “[...] gedachte Harmonia [ist] gründlich bey ihme [Paracelsus] zu finden, die er ohn zweiffel den Gelehrten mitgetheilet hette, da er sie grösserer Kunst, dann subtiles vexirens würdiger befunden, wie er dan auch mit freyem unachtsamen Leben seine zeit verlohren und der Welt ihre thörichte Frewde gelassen."

174 For the microcosm-macrocosm analogy in Paracelsus' work, see, for example: Paracelsus, Das Buch Paragranum, I, 8; 33-221.

175 Paracelsus, Begleitbrief an Clauser (1527), I, 4; 71: “[...] Italorum vero Marsilius medicorum optimus fuit." On Paracelsus and Ficino, see: Schütze, "Zur Ficino-Rezeption bei Paracelsus." 
harmony he described between man and the world. ${ }^{176}$ That both Christian Rosencreutz and Paracelsus relied on the microcosm-macrocosm analogy is a final similarity between the two.

As is clear from the passages above, the anatomy of the universe was thought to reflect the anatomy of human beings. This is reminiscent of views expressed by Paracelsus, who understood human beings as having an image which mirrors the external world. While Andreas Vesalius (1514-1564) and Michael Servetus (1511-1553), for example, conducted anatomical investigations by which they corrected Galen's anatomy-with Vesalius' famous On the Fabric of the Human Body (1543) being published by Paracelsus' former assistant, Oporinus-Paracelsus used the term "anatomy" to refer to the inner framework of man. ${ }^{177}$ The physician should probe beyond the appearances, but not through dissection, in order to see the inner anatomy, the Biltnus or image of man. According to Paracelsus, humans were intimately related to the universe through astral and supernatural influences. For him, they contained within themselves all things in the universe, its entire pattern including all elements and, beyond the earth, the firmament. Man and the cosmos were thought to be different from each other in appearance, in form, and in figure. But in "scientia," a word used by Paracelsus in an unusual way, meaning something like '(the study of) invisible reality', they were similar: "From this it follows that heaven and earth, air and water are a human being in scientia, and the human being is a world with a heaven and an earth, with air and water, similar in scientia. So Saturn of the microcosm takes after Saturn of the heaven [...]," as do the other internal planets. ${ }^{178}$ Not only all earthly elements but also all heavenly stars had their counterparts in human beings, in similarity to the medieval melothesia, the image of man with his parts assigned to the different signs of the Zodiac.

176 Forshaw, "Marsilio Ficino and the Chemical Art," $265 \mathrm{ff}$.

177 Paracelsus, Opus Paramirum, I, 9, 62: "Aber nicht anderst ist zugedenken und zuwissen, dan das alle ding in dem bild stent. Das ist alle ding sind gebildet. In diser biltnus ligt die anatomei. Der mensch ist gebildet; sein biltnus ist die anatomei, eineim arzt voraus notwendig zuwissen $[. .$.$] , zu solcher biltnus der anatomei sollen wir uns fleißen, dan on die$ wird uns die natur nicht arzt heißen"; see also: Weeks, Paracelsus, 21-47, especially pp. 3132.

178 Paracelsus, Opus Paramirum, I, 9; 95: "Darauf so folgt nun das himel und erden, luft und wasser ein mensch ist in der scientia, und der mensch ist ein welt mit himel und erden, mit luft und wasser, dergleichen in scientia. also nimpt der saturnus microcosmi an saturnum coeli, [...]." Paracelsus' theory of the elements, in which fire was replaced by heaven as a superior element, was taken over by several later Paracelsians; see, for example: Roeslin, De opere Dei creationis, 11-12. 


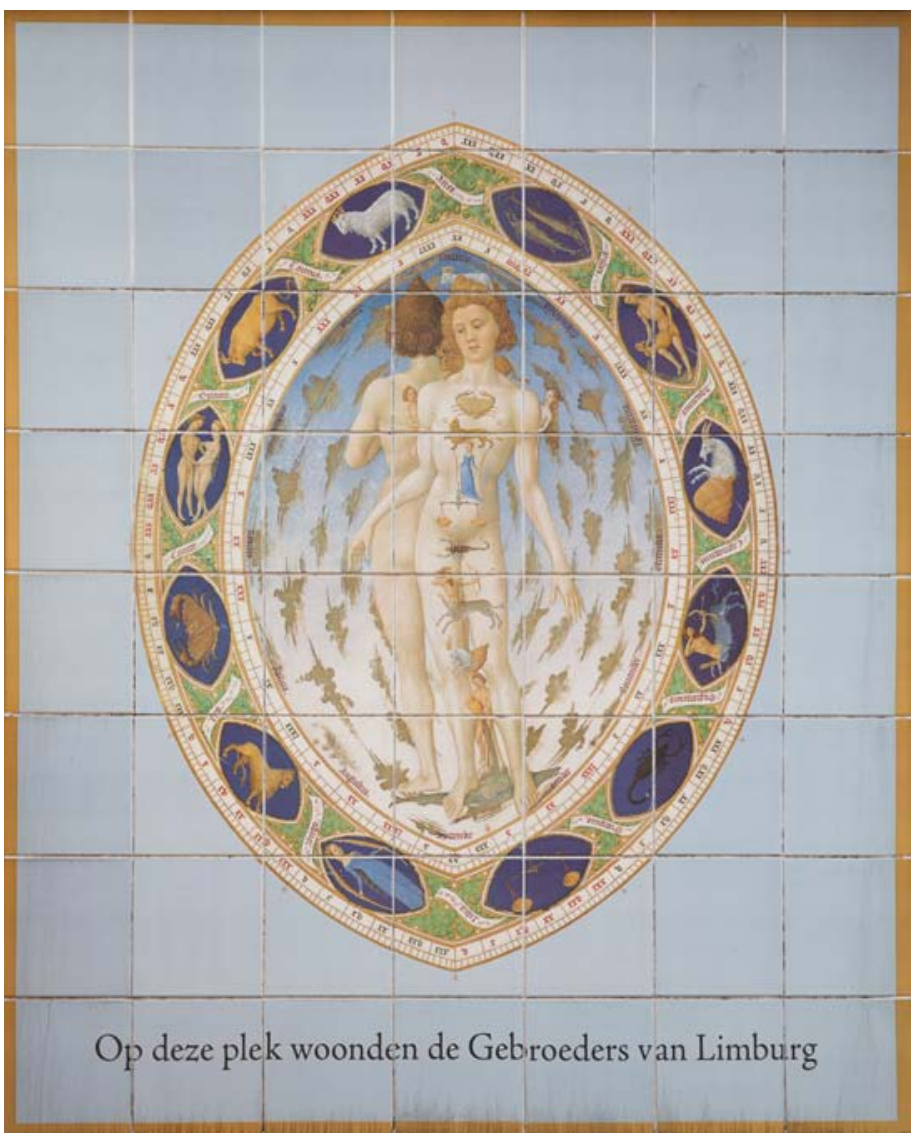

FIGURE 6 Limbourg Brothers, The Anatomy of Man, contemporary reproduction in tiles, Nijmegen

Corresponding to these philosophical views, Paracelsian medicine worked from the supposition that the world-God's creation — was a complex aggregation of individual entities linked together through sympathy and antipathy, astral influences, and magical and invisible powers. As described in his Volumen Paramirum, diseases could be caused by bad food, the human constitution, the imagination, astral influences, or by God. ${ }^{179}$ Paracelsus used the microcosmmacrocosm analogy to the advantage of his medicine. By observing the signs, or symptoms, of the disease, he searched for the corresponding cure in nature.

179 On the influences of diseases, see: Paracelsus, Volumen Paramirum, I, 1; 165-239. Here, Paracelsus described 5 entia (origins of diseases), namely ens astrale, ens veneri, ens naturale, ens spirituale, and ens dei. 
From the microcosm-macrocosm analogy it follows that something in the external world could cure humans, that is, "the external member is a medicine to the internal member," to the illness shown through its symptoms. ${ }^{180}$

To Paracelsus, this understanding of man as microcosm was related to his Signaturenlehre, the belief that there are signs in nature that reveal the essence of things and diseases. ${ }^{181}$ Everything in nature was seen to be endowed with hidden virtues or powers (Kräfte), which are revealed through signs. According to Paracelsus' theory of signatures, the form of an object reveals its essence. For example, if something is crooked in its form, it probably is so also in its essence. The possibility of understanding a thing's essence or "virtue" through its form allowed Paracelsus to find in nature medicines for ailments and apply the cure on the basis of the homeopathic principle of 'like cures like', which had earlier been used also by Hippocrates. The remedies to the disease found in nature were believed to carry the same "virtues" as the disease itself. ${ }^{182}$

These signs in the visible world, in the macrocosm, correspond to the arcana, the secrets, of the invisible world: 183

Thus nature has ordained that the outer signs indicate the inner works and virtues, thus it has pleased God that nothing will remain hidden, but that through the sciences it will be revealed what lies [hidden] in all creatures. ${ }^{184}$

The signs reveal the essence, or anatomy, of a thing. Through the signs, "the secrets of hidden, invisible things" were recognised and discovered. ${ }^{185}$ The

180 Paracelsus, Opus Paramirum, I, 9; 94: "aus solches so ist das eußer glid des innern glids arznei."

181 Edighoffer suggests that the theory of signatures is also found in the manifestos, but there is no evidence in these texts that supports this; see: Edighoffer, "Die Manifeste der Rosenkreuzer," $164-165$.

182 Paracelsus, Opus Paramirum, I, 9; 94-95; idem, Astronomia Magna, I, 12; 173.

183 Idem, Opus Paramirum, I, 9; 97.

184 Idem, Astronomia Magna, I, 12; 177: "Also hat die natur verordnet, das die eußern zeichen die innern werk und tugent anzeigent, also hat es got gefallen, das nichts verborgen bleibe, sonder das durch die scientias geoffenbart würde, was in allen geschöpfen ligt."

185 Ibid., 173-175: "Dieweil nichts so heimlichs im menschen ligt, es muß geoffenbaret werden, so wissent, das solches geschicht in dreierlei weg: durch die zeichen der natur, das ist, durch das signatum, durch welches nichts verschwigen bleibt, und zum andern durch selbs angeben [...] also zum dritten durch göttlich urteil [...]. Also mag nichts im menschen sein, das nicht außerhalb von im bezeichnet werde, durch welchs der mensch erkennen mag, was in dem selbigen sei, der das signum signatum tregt. und zugleicher weis wie ein arzt sein kunst hat in der erkantnus, die er nimpt aus dem signo signato, also 
physician should read the characters visible in the macrocosm like the letters of a book, and use them to prepare a medicine for the microcosm, thereby opening up all the mysteries hidden in nature. For Paracelsus, the microcosm and the macrocosm indeed mirrored each other.

Similar ideas were expressed in On the Internal Signatures of Things (1609) by the alchemist and Paracelsian physician Oswald Croll. Croll described the analogy between the microcosm and the macrocosm, and proposed tables of correspondences between the two. He explained how herbs and plants can work as a medicine for the microcosm based on their signatures, and which plants correspond to which diseases. Euphrasia (eyebright) and Paris quadrifolia, for example, correspond to the eyes, and can therefore be used to treat ocular problems, whereas the fruit citrium corresponds to the heart and could help in heart diseases. ${ }^{186}$

Several other Paracelsians also emphasised this analogy between microcosm and macrocosm in their works. Julius Sperber referred to the inner anatomy of human beings and explained that "the human being, as the microcosm" was in harmony with the macrocosm. ${ }^{187}$ Bodenstein's reference to the Emerald Tablet revealed that he, too, believed the microcosm to be in harmony with the macrocosm, and that the efficacy of medicine depended on this correlation. ${ }^{188}$ He further claimed that:

In the third place, they [sc. the doctors] encounter the elements and everything that emerges from them, through which the individual parts of the greater and smaller world, that is, of human beings, are known. Because the parts of the two worlds correlate to one another in a certain proportion, connection, and necessity. ${ }^{189}$

auch der astronomus in dem signato, das ist so den der himel fürstelt [...]. vier ding seind, durch die die natur den menschen offenbar macht und ein ietlichs gewechs, das verstehet also. in den vier künsten werden die heimlikeiten der verborgnen unsichtbarn ding erkant und erfunden, nemlich als durch chiromantiam." Paracelsus also names astronomy, philosophy, and medicine.

186 Croll, Tractatus de signaturis internis rerum, seu de vera \& viva Anatomia maioris \& minoris mundi, 19, 21.

187 Sperber, Von den dreyen seculis, 208-209: "Und endlich/ was die innerliche und warhaffte Anatomia des Menschen seye? Wie nemlich der mensch/ als der Microcosmus, fast in allen dingen mit der Welt/ und also mit dem Macrocosmo (davon der Weise-mann mysticè etwas andeutung thut) sich vergleicht/ und mit demselben in gar richtiger harmonia ganz arthlich überein komme?"

188 Cf. below, p. 157 .

189 Bodenstein, $C P$, vol. 1, nr. 7, 153: "Tertio loco elementa occurrunt, et quaecunque ex ipsis nascuntur, quo maioris ac minoris, hoc est hominis, singulae partes sint notae: Cohaerent namque partes utriusque mundi certa proportione, cognatione et necessitate [...]." 
Toxites referred to this analogy in his edition of Paracelsus' Astronomia Magna:

The human being has not been made out of nothing like heaven and earth, but from a matter, that is, from the great world, which is why he is also called 'microcosm'. Because everything that is essentially in heaven and on earth, is also spiritually in the human being. ${ }^{190}$

Human beings were similar to the external world, but, again, only in what Paracelsus called the human Biltnus, their image. For Toxites, this meant that human beings were the most exalted of all of God's creatures: "The human being should be correctly acknowledged as the most noble creature, and should be held in high esteem by many, not only because he is the microcosm and a miracle of the world, but rather because God created him in His image."191 With this claim, Toxites associated himself with the Renaissance philosophy of, amongst others, Giovanni Pico della Mirandola. For both Toxites and the manifestos, humans as microcosms mirror not only the external world, but, echoing Genesis 1:26, also God: "And God said, Let us make man in our image, after our likeness [...]."

Such ideas in the Paracelsian movement obviously exercised an influence on the authors of the manifestos and occupied a prominent place in their plans for the announced reformation. Paracelsus was remembered for having studied and described such powers and structures of the universe, while not only he, but also some of his early followers held such views. Although these ideas were not solely Paracelsian and some of them had a long history also in other traditions, the Rosicrucian manifestos explicitly associated them with Paracelsian thought. Owing to such ideas, Paracelsus was understood to have been a forerunner of the Rosicrucians. Paracelsus was thus neither regarded as a practitioner of transmutational alchemy, nor mentioned as a medical innovator, but he was instead heralded for his Hermetical-philosophical views. This is a cru-

190 Toxites, preface to Astronomia Magna, Aiiiv: “[...] Dann der Mensch ist nit auß nichts wie himmel und Erden/ sonder auß einer materia/ das ist/ auß der grossen Welt/ gemacht worden/ daher er auch Microcosmus genennt wirt. Dann alles was in Himmel und Erden wesentlich ist/ das ist auch im Menschen geistlich [...]."

191 Ibid., Aiir-Aiiv: "[...] so soll der Mensch billich als die Edlest Creatur recht erkennt [werden]/ und in hohen Ehren von meniglichen gehalten werden/ nicht allein daß er Microcosmus/ und ein miraculum Mundi ist/ sonder viel mehr darumb daß ihn Gott ihm zum Bildtnuß geschaffen [...]." Pico had different reasons for granting man this position, but in his view also, man has every aspect of the external world within him; see: Pico, Oration on the Dignity of Man, theses 1-23, 27-30. 
cial point, because anti-Paracelsian physicians of the time, such as Andreas Libavius (1555-1616) and Thomas Erastus (1524-1583), criticised Paracelsian medicine not so much for its chemically prepared cures, but instead for its natural-philosophical concepts, such as the microcosm-macrocosm analogy and the theory of signatures. These were the exact elements in the manifestos that were explicitly associated with Paracelsus, which means that it was this Paracelsian philosophy that was to become the foundation of the new age. ${ }^{192}$

\subsection{Primeval Wisdom}

The microcosm-macrocosm analogy corresponded to ideas in the Hermetic tradition, which was a movement related to the tradition of a philosophia perennis. In the years before the manifestos were drafted, Paracelsus had come to be known as the German Hermes Trismegistus, a title that appeared on several of his posthumous publications, including those edited by Huser. ${ }^{193}$ The Rosicrucian authors drew some of their inspiration from these traditions, as they claimed to be the inheritors of the primeval wisdom known to some ancients in the far past, which was to serve as the foundation for their "citadel of truth."194 Their philosophical renovation was therefore at the same time also a restoration of a long-lost philosophy. Through God's revelation and the study of nature one could still acquire divine knowledge, even after the Fall. A similar idea of a primeval philosophy coming back to light is found in the Paracelsian tradition. Paracelsus himself had been equivocal in his statements about ancient wisdom. In his On Elevating the Hearts, he referred to ancient figures and biblical ones as having been led "by a divine voice,"195 but else-

192 On Libavius, see below, section 5.1. See further: Erastus, Disputationes de medicina nova Paracelsi; Libavius, Examen philosophiae novae; Gunnoe, "Thomas Erastus and his Circle of Anti-Paracelsians"; idem, "Erastus and Paracelsianism"; Shackelford, "The Early Reception of Paracelsian Theory"; Moran, "Medicine, Alchemy and the Control of Language"; idem, Andreas Libavius and the Transformation of Alchemy.

193 Kühlmann, "Der 'Hermetismus' als literarische Formation"; idem, "Paracelsismus und Hermetismus"; Kühlmann and Telle, Corpus Paracelsisticum, vol. 2, 27-38; Gilly, "Vom ägyptischen Hermes zum Trismegistus Germanus."

194 Fama, 123-124; Confessio, 49.

195 Paracelsus, Liber de sursum corda, NPE 1, 462: "Was aber gesein ist in Abraham, Isaak, Jakob, in Moses, in David, in Salomon, in Esaia, in Jeremia etc. und andere dergleichen mehr, dieselbigen alle, wieviel ihr seind under denen, die seind von göttlicher stimm und über die inspiration darzu geweisen und geführt worden. Und ist nichts gesein us der inspiration, das so sie gehandelt hont, sunder us gott hernach geben, us beschehen ursachen, so gott darzu geursacht." 
where he claimed that only God and Christ possessed the truth. ${ }^{196}$ Generally for Paracelsus, true wisdom comes only from Christ, and only true Christians could acquire true wisdom - all those preceding Christ had fallen short of that standard.

The author of On the Tincture of the Natural Philosophers, in turn, having used the name of Paracelsus pseudonymously so that, at the time the manifestos were written, his text was thought to have been drafted by Paracelsus, spoke highly of Hermes Trismegistus. He argued against an unnamed "sophist" that "the Emerald Tablet [of Hermes] gives evidence of even more art and experience of philosophy, alchemy, magic, and so forth, than could ever be learned by you and your gang." ${ }^{197}$ Pseudo-Paracelsus thus incorporated the Hermetic tradition into his understanding of Paracelsianism.

Similarly, just before the manifestos were published, Sperber claimed that true wisdom had already been known to Adam. Originally written in 1597, one anonymous editor dedicated Sperber's About the Highest Treasures to the Rosicrucian brotherhood when it was eventually published in 1615 as the Echo of the Divinely Illuminated Fraternity and Commendable Order of the Rose ${ }_{2}$ Cross. ${ }^{198}$ In the original preface of 1597 , entitled Preface to the Christian reader, Sperber claimed that "Adam has after the Fall kept all sorts of insight and knowledge of such divine wisdom in his memory," and that now humans could once again "come to the attainment of such wisdom of God."199 This resonated with

196 Idem, De summo et aeterno bono, II, suppl.; 14: "Salomon und andere seindt nit unsere vorgeher, allein Christus!"; idem, Liber de venerandis sanctis, NPE 1, 425: "Wieviel mehr ist er dann gegen gott, dass er uns sein reich des himmels offenbart hie uf erden, was dasselbig sei, wie wir darein sollen kommen. Wer wollt uns das gelernt haben unter allen uns schädlichen menschen? Nit Abraham von ihm selbst, nit Moses, nit David, nit Salomon, nit Plato, nit Cato, allein der vom himmel ist, der kann uns die wahreit sagen."

197 Pseudo-Paracelsus, De tinctura physicorum, I, 14; 391: "So zeigt die alt schmaragdinische tafel noch mer kunst und erfarung der philosophei, der alchimei, der magica und der gleichen an, dan imermer von dir und deinen haufen wird gelernet werden." See also: ibid., 392-393.

198 Sperber, Von der höchsten/ allerbesten unnd thewresten Schätze, republished in the Echo, 1615. Gilly doubts that Sperber was the author of the About the Highest Treasures (Echo), see: Gilly, Johann Valentin Andreae, 31. Here, we will refer to him as the author of the text, but his authorship should be studied carefully in future literature.

199 Sperber, "Preface," Von der höchsten Schätze, 5: "[...] hat doch Adam nach dem Falle von solcher Göttlichen Weißheit allerley Erkändtnuß vnnd scientias im Gedächtnüs behalten/ sonderlich aber den weg/ dadurch man widerumb (so wese [?] und viele als dem Menschen nach dem falle von Gott vorgünstiget und zugelassen) zu erlangung solcher Weißheit Gottes kommen kan." See also Sperber's Von den dreyen seculis (1597/published 1660). 
a statement in the Fama's that "our philosophy is nothing new but is the same which Adam received after his Fall." 200

Sperber's view was akin to that of Steuco, as well as to that of Ficino, who had provided a genealogy of ancient wisdom starting from Hermes through Orpheus, Pythagoras, and Plato through to later authors. Ficino believed that Hermes was, if not identical with Moses, then at least a contemporary of Moses, thereby linking the Egyptian and Greek lines of true wisdom with the knowledge of the foremost prophet. ${ }^{201}$ For Sperber, original and true knowledge was a pious philosophy, which in his opinion entailed primarily magic. From Adam it was passed down to Abraham and Zoroaster, and "from this Zoroaster such an art descended afterwards to the Chaldeans and then to the Persians, who used it for a long time like the Egyptians [...]. The excellent scholar Plato says about this magic that it is a cult of the gods."202 This magic, Sperber explained, "is nothing but the pious wisdom, that is a beatific wisdom," ${ }^{203}$ which had also been known to the Jewish Kings David, Samuel, and Solomon, and their disciples. It was termed Kabbalah by the Jews and was ultimately known to Christ and his mother Mary. ${ }^{204}$ Christ had then started his own magical school to further disseminate the divine wisdom-identifying original wisdom with Christian thought. ${ }^{205}$ Compare this again with the Fama: "[...] wherein Plato, Aristotle, Pythagoras, and others recognised the truth, for which Enoch, Abraham, Moses and Solomon provided the crucial argument, and which above all is consistent with that wonderful book, the Bible - all of it comes together."206

200 Fama, 123-124: "unser Philosophia ist nichts newes sondern wie sie Adam nach seinem Fall erhalten."

201 On Steuco, see above, section 1.3. Ficino, Platonic Theology, II, 125; IV, 61; VI, 83.

202 Sperber, "Preface," Von der höchsten Schätze, 7-8: "Von dies ein Zoroaster ist nu solche kunst hernacher auff die Chaldeer und folgends auff die Persianer kommen, bey welchen sie wie auch bey den Egyptern sehr lange im brauch gewesen [...]. Der treffliche Gelehrte Mann Plato beschreibet die Magiam das sie sey eine cultus Deorum."

203 Ibid., 8: "Dann magia ist ein Persianisch wort/ wie Porphirius bezeuget/ So gibt es der Persianischen Sprach art und eigenschafft/ das es nicht anders sey, denn pia sapientia, das ist eine Gottselige weißheit [...]."

204 Ibid., 17-18: "In solcher Schule werden nu unzweiffelich immer nacheinander/ ob wol nicht viele/ jedoch nützliche Discipuli ein erzogen worden/ vond enen erzliche dieses hohe studium auff Samuel, David, Salomon Discipulen/ unnd biß gar auf den Priester Esoram kommen [...] wie er dan auch von deß HErrn Christi und seiner Mutter Marien künfftigen zustand gweissaget. Mit diesen beyden hat nun diese höhste Kunst der Gottlichen Weißheit im alten Testament auffgehöret."

205 Ibid., 20.

206 Fama, 123-124: “[...] worinnen es Plato, Aristoteles Phytagoras und andere getroffen, wo Enoch, Abraham, Moses, Salomo den außschlag geben, besonders wo das grosse Wunderbuch die Biblia concordiret, das kömmet zusammen [...]." 
Pious wisdom and primeval wisdom were identified in both the Fama and in Sperber's preface to About the Highest Treasures, in line with traditions such as the Mosaic physics.

According to Sperber, this original wisdom had been lost, because after the era of the saints "this high study [...] was increasingly more forgotten [...] so that it could unfortunately happen that almost in the entire world one does not know anything specific anymore about this holy and very high discipline." ${ }^{207}$ Still, it was not entirely lost, because "in all ages one could find among Christians some individual and very few people, who were inclined to such a study," among whom Sperber listed mystics, Neoplatonic philosophers, and Cabalists such as Cornelius Agrippa, Johannes Reuchlin, Johannes Tauler, Marsilio Ficino, Guillaume Postel, and Giovanni Pico della Mirandola. ${ }^{208}$ Sperber believed that the original philosophy had come to light and was preserved in the thought of these authors who drew on ancient arts and philosophy, and who defined their own ideas as explicitly Christian in nature.

Sperber, as if expressing the aims of the Rosicrucian brotherhood, wanted to found a society on the basis of this rediscovered pious wisdom for anyone who took an interest in his book, so as to discuss magic and secrets and to spread original and divine wisdom. The good reader, he noted, "should not doubt me that he will read this work with great use and benefit, and that he will find in it explained many passages from the Holy Scripture, which had previously appeared somewhat obscure to him.." ${ }^{209}$ Like the manifestos after him, Sperber

207 Sperber, "Preface," Von der höchsten Schätze, 24: "also ist auch dieses hohe studium von derselben Altvater zeiten der Heiligen je lenger je mehr vergessen [...], also das es leider darhin gerahten das man von solchem heiligen und aller höchsten studio fast in der ganzen Welt nichts mehr sonderliches weis."

208 Ibid., 25-26: "man noch zu jeder zeit, wiewol allein einzlich unnd sehr wenig Leute, unter den Christen gefunden die ihnen solch studium haben angelegen sein lassen, darzu auch etwa mediate et inmediate andeutung und nachweissunge bekommen. Als der sonderlich gewesen sein (wie aus ihren Schrifften zum theil abzunehmen): Heinricus Cornelius Agrippa; Aegidius de Roma; Gerhardus Zurphaniensis; Johannes Hagem de Indagine; Johannes Reuchlinus; Taullerus ein Prediger Münch; Perrus Galatinus und Franciscus Georgius beyde Minoritaner Münche, Marsilius Ficinus Theologus, und Medicus Guilhelmus Postellus, Henricus Harpius Theologus, Picus comes Mirandulanus; Marcus Antonius Mocenicus ein Venetiamscher patricius und Stephanus Conventius und andere mehr [...]." Most, if not all of these men had studied magic and Cabala.

209 Ibid., 40-41, 50: "[...] der gutherzige Leser [...] zweiffelt mir alsdann nicht, er werde solchen tractat mit grossem nutz und frucht lesen, auch im selben viel örter der heilgen Schrifft so ihme zuvor etwas dunkel werden furkommen sein, deutlich und wol erkläret finden." 
believed that the primeval wisdom of the ancients expressed biblical secrets, was witnessing a restoration, and was to become the new philosophy for the new age.

We have already seen that Bodenstein believed that the newly restored medicine had once been practiced and conveyed by Hermes Trismegistus, and that he borrowed from both Hermeticism and the philosophia perennis. He emphasised the link with original pious thought by bringing the wisdom of the ancient philosophers in line with the knowledge of the Church Fathers and interpreters of the Holy Scripture:

When they [sc. the Church Fathers and interpreters of the Bible] for the first time received the rules and revelations of God and perceived His miracles, they dedicated themselves first and foremost to a divine philosophy, which is manifest in the Cabala, in Mercurius Trismegistus, Berosus, ${ }^{210}$ Orpheus, Pythagoras, Plato, and the entire philosophy of the Egyptians, Chaldeans, and Assyrians. All of them taught much about the spirit, God, about the divine and secret causes. After Plato the Greeks fell for the most part from this more noble philosophy to a cruder and rudimentary philosophy. 211

Bodenstein compared the divine wisdom of the earliest philosophers also to theology. ${ }^{212}$ Thus knowledge of the ancients, understanding nature through magic and Cabala, had in Bodenstein's view provided a wisdom similar to Scripture, and was likewise studied by the Church Fathers.

In some pseudo-Paracelsian texts, specifically alchemy was used for the purpose of bringing back to light ancient knowledge. The pseudo-Paracelsian Apocalypse of Hermes and On the Tincture of the Natural Philosophers purported to reveal the "secret of secrets." According to On the Tincture, this secret had been sought and found by Hermes Trismegistus, [pseudo-]Aristotle, ${ }^{213}$ Avicenna, Albertus Magnus, and others, and it combined ancient wisdom and divine

210 Pseudo-Berosus, i.e., Annius of Viterbo (ca. 1432-1502), who published his forgery in 1498.

211 Bodenstein, $C P$, vol. 1, nr. 6, 115: "Nam, primi Dei praecepta et reuelationes, ubi [patres sacrarum literarum interpraetes] acceperunt, et miracula uiderunt diuinam philosophiam maximè coluerunt, quod liquet in Cabala, in Mercurio Trismegisto, Beroso, Orpheo, Pythagora, Platone, totáque philosophia Aegyptorum, Chaldaeorum et Assiriorum. Illi, de mente, Deo, diuinis et ocultis causis multa docuerunt. Post Platonem Graeci maiori ex parte à nobiliori defecerunt ad crassiorem et elementarem [...]."

212 Cf. Fama, 123-124; see above, section 1.3.

213 The author presumably refers to pseudo-Aristotle, Secretum secretorum. On this text and its circulation, see: Williams, The Secret of Secrets. 
secrets. The sought-after ancient secret was an alchemical preparation that would counteract bane, return youth, and prolong life-one of the key functions of the philosophers' stone. ${ }^{214}$ This stone, the quinta essentia, was said to be prepared alchemically in order to restore health, and was referred to as the "lily of medicine and alchemy," or "the most quiet and highest secret of nature, that is, the spirit of the Lord." 215 In similarity to the restoration of divine secrets, medicine was also thought to reverse the consequences of the Fall. This medicine was the Spirit of the Lord, meaning that God himself was responsible for the restoration of original purity and that He had revoked His original punishment, granting some humans access to His Spirit through their work in alchemy.

That this material could counteract the consequences of the Fall was made explicit in the pseudo-Paracelsian Apocalypse of Hermes, which reads: "Then our ancestors Adam and Eve were given death as punishment, which cannot be separated from their descendants." But the treasure that was hidden in all "elemental creatures" was found again by a few, among whom notably Hermes and Aristotle, who named it the "secret of secrets." It was this treasure "from which Adam and the other Patriarchs had had their bodily health and long life."216

214 Pseudo-Paracelsus, De tinctura physicorum, I, 14; 391-399. Cf.: Pseudo-Paracelsus, Apocalypsis Hermetis, edited by Zetzner (16o3), part 2, 668-671.

215 Pseudo-Paracelsus, De tinctura physicorum, I, 14; 393: "ich werde euch lernen die tinctur, die arcana, oder das quintum esse, in welchem alle heimlikeit, grunt und werk ligt." Ibid., 394: "Darumb die materia tincturae das größt perlin und edlester schaz ist, das nach des almechtigen eröfnung und aller menschen betrachtung auf erden sein mag. und is die lili der arznei und alchimei, welche die philosophi so heftig und streng gesucht haben, aus gebresten ganzer erkantnus und volkomner bereitung, doch nicht perfect zum end gebracht." Ibid., 398-399: "Das ist die tinctur, dardurch etliche von den ersten physicis in Egypten, wie dan auch noch auf dise zeit, hundert und fünfzig jar gelebt. viler vita hat sich aug lengert und etwan auf etlich secula erstrekt, wie die historien offentlich ausweisen und solchs doch niemants glaubwürdig gedünkt. dan ir kraft ist so wunderbarlich, das sie den leib höher, dan die angeboren cimplexion erzeigt, bringt, und in dem selben grad stanthaftig erhelt, das er vor allen krankheiten frei bewart und ob er mit alter behaft scheinet, gleichsam seiner vorigen jugent zugestelt were [...]. Dan das ist die catholicum physicorum, darumb das alle physica dem langen leben seind nachgangen"; cf. PseudoParacelsus, Apocalypsis Hermetis, 670: "Diese Göttliche Werck ist gar zu tieff/ daß es kein Narr verstehen kan/ dann es ist das leiste und höchste Geheimnuß der Natur/ das ist/ der Geist deß Herren/ [...]."

216 Pseudo-Paracelsus, Apocalypsis Hermetis, 668: “[...]. Dann unsern voreltern Adam und Evae/ ist der Todt zur straff auffgesetzt worden/ das sich von ihren nachkommnen nicht scheiden laßt. Dahero offtgedachter Philosophus, und andere viel mehr/ dasselbig Einig vor allen dingen mit grosser Arbeit gesucht/ und haben befunden/ daß dasselbige/ welches dann den menschlichen Leib von seinem verderben enthalt/ und das leben erlengert [...]. Das geistlich Wesen/ diß einig ding/ ist dem Adam von oben herab geoffen- 
The rediscovered secret was hidden throughout nature and had the capacity to restore and improve health, and presumably worked as panacea, as a cure to all diseases. Both the instauration of lost knowledge and the regeneration of the body would counteract the consequences of the Fall and enact a reversal of original sin.

The elemental creatures were beings living within the four elements. They were discussed by Sperber and in the pseudo-Paracelsian Liber Azoth. ${ }^{217}$ Paracelsus had described these creatures earlier, for example in On the Long Life, which deals, as the title suggests, with longevity, and which work was edited by Bodenstein in 1560 and $1562 .{ }^{218}$ The theme of longevity returned in the Brief Consideration of the More Secret Philosophy to which one of the first editions of the Confessio was appended in 1615 . This text specifically refers to Paracelsus several times, including one reference to his On the Long Life. ${ }^{219}$

Both the elemental figures and the notion of longevity return also in the Rosicrucian manifestos. According to the Fama, Christian Rosencreutz was educated by elemental beings in Fez about various unnamed secrets of nature-which again indicates his knowledge of what was hidden beyond the surface in nature. ${ }^{220}$ Likewise, not only the rediscovery of lost knowledge and the return of prelapsarian conditions were mentioned in the Rosicrucian manifestos, but also the restoration of the original human body. According to the Fama, the bodies of the Rosicrucian brethren remained healthy throughout their entire lives. They died, but not as a result of diseases, but because it was time for their spirits to return to God.221 They could keep their bodies healthy thanks to the panacea, which the brethren claimed to have in their possession. This means that they could restore bodies to paradisiacal conditions. ${ }^{22}$

baret worden/ und von den heiligen Vättern sonderlich begert worden/ welches Hermes und Aristoteles, das wahre/ ohne lugen/das gewiste/ das aller gewisseste/ das Geheime aller geheimen nennen [...]. Und wie die Seel in allen gliedern des Leibs ist/ also findt sich dieser geist in allen Elementirten geschöpffen: wirdt gesucht von vielen/ von wenigen aber gefunden [...] auß welches krefften der Adam und die andern Patriarchen ires Leibs gesundtheit und langes leben gehabt haben."

217 Sperber, Von den dreyen seculis, 208; Pseudo-Paracelsus, Liber Azoth, I, 14; 582-583.

218 Paracelsus, De vita longa, I, 3; 249-292. For elemental forces in other works by Paracelsus, see: Paracelsus, Astronomia Magna I, 12; 3-507; idem, Paragranum, I, 8; 135f.; Weeks, Paracelsus. Essential Theoretical Writings, 12, 17, 26, 28, 30, 130; idem, Paracelsus, 9.

219 Philippo à Gabella, Secretioris philosophiae consideratio brevis, 11, 39, 41; Clulee, "Astronomia inferior," 218. On the manifestos' association with this text, see below, section 3.1.

220 Fama, 96-97.

221 Fama, 108, 119.

222 Elsewhere, perfect bodies were merely mused upon: Confessio, 47-48: "Qui itaque sordeant nobis tanta; si Nobis tantum haec scire, et non potius seculi sui ornamento data 
The Rosicrucian reformation of philosophy consisted in bringing back the pious wisdom of the ancients, and possibly even prelapsarian conditions and perfectly healthy bodies - intentions that had earlier been voiced in the works and thought of Paracelsus and his followers. The instauration of such knowledge was fundamental to the Rosicrucian general reformation.

In Sperber, we find a writer who expressed further ideas similar to the Rosicrucian reformation. Before the manifestos had been drafted, he specifically wrote about the reform of theology, medicine, and philosophy. With respect to theology, Sperber characterised the first age by the Jewish theology of the law; the second age by a Christian theology, and "in the last time there will be a theology of the Holy Spirit, which is named by Johannes an eternal gospel: An angel will announce it, to those who will dwell and live on earth." ${ }^{223}$ This clearly resonates with Joachim's three statuses or ages: the age of the Father or the Old Testament, the age of the Son or the New Testament, and the age of the Holy Spirit.

In medicine, Sperber argued, some changes for the better had already occurred. While in the first age, physicians practiced an empirical medicine, and in the second age a rational medicine, "in the last time of the Holy Spirit there will be the chemical or spagyric medicine."224 Although Sperber, like the manifestos, did not explicitly refer to Paracelsus in this sense, the spagyric art of which he speaks is obviously Paracelsian. While discussing medicine, he reiterated Paracelsian elements relevant to medicine such as the microcosm-

essent? Qui non libenter in una veritate, quam per tot anfractus, tot labyrinthos quaerunt Mortales, libenter acquiesceremus, si Candelabrum sextum nobis tantum lucere Deus voluisset? Nonne satis erat Nobis, nec famem, nec pauperiem, nec morbos, nec senium metuere? Nonne praeclarum, sic in qualibet hora vivete, quasi à Mundo nato vixisses: quasi ad Mundi interitum victurus esses? [...] sic legere in uno libro, ut quidquid omnes libri, qui fuerunt, sunt, prodibunt, habuerunt, habent, atque habituti sunt, legas, intelligas, retineas? [...] O Mortales, aliud est consilium Dei et commoditas vestra, cui decretum Fraternitatis nostrae numerum hoc Fraternitatis tempore augere atque multiplicare."

223 Sperber, Von den dreyen seculis, 42: "Zur zeit des Vatters im ersten Seculo und Testament ist gewesen die Judische Theologia oder Religion/nemlich das Gesetz. In der zeit des Sohnes im Newen Testament haben wir bißhero gehabt und haben noch die Christliche Theologiam oder Religion/ nemlich das Evangelium der Gnaden Gottes/ und unsers heyls [...]. In der letzten zeit wird seyn die Theologia des Heiligen Geistes/ welche Johannes nennet ein Ewiges Evangelium: Welches ein Engel wird verkundigen denen die auff erden sitzen unnd wohnen/ [...]"; see also: ibid., 165 .

224 Ibid., 80-81: "In der zeit des Vatters war im brauch die Empirische Medicina, welche allein auff gewisse experimenta oder erfahrung gerichtet gewesen [...]. In der zeit des Sohnes it auffkommen die jenige Medina [sic], welche man Rationalem nennet [...]. In der letzten zeit des Heligen Geist wird seyn die Chymische oder Spagyrische Medicina." 
macrocosm analogy, the inner anatomy of man, and, notably, the influence of the imagination on diseases. ${ }^{225}$

Philosophically, "in the third and last age will come and remain in highest perfection and certainty another perfect and permanent philosophy, together with the seven liberal arts."226 As already described above, also for Sperber this state of perfection resonated with primeval wisdom, so that he combined the philosophia perennis with the traditional medieval liberal arts. In that future age, magic, the divine wisdom, would also be perfect. ${ }^{227}$ Previously a secret and hidden wisdom, magic in the last age will be entirely revealed. ${ }^{228}$

The reform described by Sperber differed in its details from that of the brethren, but the overall framework, that is, the changes within the fields of theology, medicine, and philosophy, on the eve of the new age, is strikingly similar. Sperber's emphasis on the reform of these areas, complemented by magic and restored wisdom, resonates with the goals of the Rosicrucian brethren's reform agenda just a few years later.

\subsection{Concluding Remarks}

In Chapter One, several elements in the manifestos were established that announced an imminent new age, but these did not specify in precisely what way the new age should be different, and from where the Rosicrucian philosophy for the new period was to come. With respect to Paracelsianism, in turn, there are few elements originating from that movement that also indicate the new age: the Antichrist and celestial portents are largely absent, and instead of a political-spiritual figure - the lion-early Paracelsians expected a figure based on Elijah, the alchemical prophet Elias Artista. Paracelsianism did not provide the context of the Rosicrucians' general reformation, but its contents. Taking into account, besides Paracelsus' medicine and philosophy, also apocalyptic themes and works by Paracelsus' followers, has enabled us to shed fresh

225 Ibid., 206-209; Paracelsus, Volumen Paramirum, I, 1; 165-239.

226 Sperber, Von den dreyen seculis, 81: "In der dritten unnd letzten zeit aber wird eine andere gewisse vollkommene unnd beständige Philosophia, sampt den sieben Freyen Künsten/ in höchster vollkommenheit unnd gewisheit aufkommen und bestandig bleiben"; see also: ibid., 210.

227 Ibid., 82-85.

228 Ibid., 219: "Und ob woll auch im ersten unnd andern Seculo diese Magia gar eine heimliche und verborgene Weißheit ist: So wird sie doch dort im letzten Seculo ganz offenbahr werden. [...] Es is nichtes verborgenes/ daß nicht offenbahr werde." 
light on the Paracelsian influence on the manifestos. Although the manifestos refer only to Paracelsus, the parallels with the early Paracelsians are unmistakeable.

In their apocalyptic views, the Rosicrucians shared very little with Paracelsus' own religious notions, ${ }^{229}$ and were much more closely aligned with early Paracelsians. Early Paracelsians, such as Bodenstein and Sperber, expected a new earthly age before the end during which all things will be revealed and Paracelsian medicine and natural-philosophy will thrive.

The new medicine advocated by the Rosicrucians must have been Paracelsian, even though they do not refer to it as such. But the figure of Paracelsus himself was no doubt inspirational, as is evident from the various references to him and the similarities between him and Christian Rosencreutz. The Rosicrucians aligned themselves with the growing rejection of scholastic thought by Paracelsus and early Paracelsians, and were aware of the new medicine and its corresponding natural-philosophical worldview that was promoted by Paracelsus and further communicated by early Paracelsian editors. Here, we may also observe the possible influence of pseudo-Paracelsian texts: Cabala, longevity, and the promise of perfect conditions and bodies-mentioned in the manifestos - can be traced back particularly to pseudo-Paracelsian writings such as On the Nature of Things, On the Tincture of the Natural Philosophers, and The Apocalypse of Hermes. ${ }^{230}$

Wels argues that the manifestos are not heterodox, and only convey a very moderate sense of Paracelsianism, one grounded in Lutheranism. ${ }^{231}$ On the contrary, more so than providing the millenarian imagery and its ingredients, Paracelsus and his followers offered the content of the Rosicrucian reformation. With respect to philosophy, the influence of Paracelsus is unquestionable, but these ideas are not as mystical as has sometimes been suggested. ${ }^{232}$ Notions such as the microcosm-macrocosm analogy and the Book of Nature are explicitly derived from Paracelsus and are a central aspect of the Rosicrucian reformation. In "the new kingdom" of Paracelsus, Paracelsian philosophy was

229 This is contrary to what has been argued in: Murase, "Paracelsismus und Chiliasmus," 1119.

230 Cf. Paracelsus, I, 14; for De natura rerum; see: Sudhoff, Bibliographia Paracelsica, 345, 392; for De tinctura physicorum, see, ibid., 189-19o, 235, 268, 392; Sudhoff, Sämtliche Werke, I, 14; xii-xvi.

231 Wels, "Die Frömmigkeit der Rosenkreuzer-Manifeste."

232 Edighoffer, for example, who perhaps discussed the Paracelsian influence on the manifestos at greater length than most, speculated about the meaning of their philosophical elements and its mystical and esoteric character; see especially: Edighoffer, Rose-Croix et société idéale, vol. 1, 270-278; idem, "Die Manifeste der Rosenkreuzer." 
to prevail at the expense of scholastic philosophy; likewise for the Rosicrucians, this type of philosophy provided the foundation for the new age.

Paracelsus' followers associated themselves with the philosophia perennis, and their many publications may have prompted the authors of the Fama to refer to a Vocabulary that would unlock Paracelsus' code. Because, as the brethren claimed, the new age was a return to the beginnings and a restoration of the order of nature, their new philosophy was-in terms contrary to orthodox Lutheranism - at the same time also a restoration of long-lost knowledge. Like early Paracelsians, the Rosicrucians identified primeval philosophy with Paracelsian thought. In particular Sperber's belief in a new age, combined with the instauration of lost knowledge and the reformation of philosophy, religion, and medicine, would have been a singular example to the Rosicrucian authors. 